Journal of Language \& Translation 11-2

September 2010, 71-148

\title{
Lexical Incongruity in Translations of American Political Speeches into Arabic: Between Presidents Bush and Obama
}

\author{
Yasmin H. Hannouna \\ UAE University
}

\begin{abstract}
This paper endeavors to investigate the extent to which it is possible to handle the translation of emotive political lexical items which have only partial or no equivalents in the target language in terms of componential analysis as a procedure of translation (Newmark 1981: 20; 1988: 115). Two professional translators participate in translating the sample texts extracted from some political speeches delivered by the American Presidents George Bush and Barack Obama for the highly emotive expressions they contain. The procedure of the study is entirely based on the analysis and comparison of two suggested translations of each sample text. The results show that Arabic political items are charged with high emotive meanings. Further, a translator should be culturally and linguistically competent in languages to produce effective and adequate translations.
\end{abstract}

Keywords: emotiveness, political speeches, translation equivalence, connotation, lexical incongruity, componential analysis 
72 Lexical Incongruity in Translations of American Political Speeches into Arabic

\section{Introduction}

Political discourses, in general, and political speeches, in particular, are intended to arouse emotional reactions towards a specific topic. Therefore, it is not easy for a translator to render English political speeches into Arabic without taking into consideration the emotive function of language and its effect on changing the emotive state of the audience. Further, a translator should be fully aware of the fact that political terms may be highly emotive in one language, but they are not so in another and their target language (henceforth, TL) counterparts may be non-congruent. Consequently rendering them in an equivalent fashion into the TL could be impossible.

\subsection{Statement of the Problem}

Producing an equivalent translation is almost an unattainable task, and any attempt that aims at providing an adequate equivalence may be deemed to be a failure. Indeed, producing adequate equivalence in translating certain Arabic texts into English or the opposite constitutes main problems to Arab translators. The writer of this paper opts for dealing with issues related to emotiveness, lexical non-equivalence and cultural expressions. The text-type reflecting all these problems is that of political speeches. Most of the extracts were chosen from some political speeches delivered by the American Presidents G. Bush and B. Obama addressing the Arabs and Muslim World for the highly emotive expressions expected to be loaded in them.

The present study endeavours to identify the extent to which it is possible to handle the translation of emotive political lexical items which have only partial or no equivalents in the TL in terms of CA as a procedure of translation whose only purpose is to achieve the greatest possible accuracy and is said to be "more precise and 
limiting than paraphrase and definition" (Newmark 1988: 115). The use of this technique to analyse certain untranslatable lexical items in the data into their semantic features is an attempt to make it possible and facilitate their translation from English to Arabic on the basis of the common emotive overtones they connote. Moreover, the study deals with the implications relevant to the translation of some lexical items that exist in both cultures, but convey different connotations, such as 'liberal', 'parliament', 'revolution' and 'bourgeois' which do not necessarily mean the same thing for an Arab and an English man.

The core of the investigation is to pinpoint instances of emotive overtones in English political speeches when translated into Arabic. This involves value judgements of the meanings of certain lexical items as negative, positive or neutral. Some emotive expressions can be congruent; others are not when their TL equivalents cannot be used to convey the same connotations. Some text-producers use neutral/objective vocabulary; whereas others use emotive/subjective vocabulary. Shunnaq (1993: 39) argues that an emotive meaning is "a function of responses to words" (i.e., certain words tend to produce emotive responses showing that there is emotive meaning). The emotive meaning of a word is "a tendency of a word, arising from the history of its usage, to produce effective responses in people."(Ibid.).

One of the problems that are intended to be investigated in the present work is relevant to the fact that there are numerous examples of lexical items which constitute a difficulty when translated into another language. An Arab translator translating certain lexical items from English into Arabic, for instance, should take into consideration: (a) the emotive aspect, (b) that the translations of certain expressions look incongruent despite strenuous efforts that would be exerted by translators and (c) in most cases, translators fail to convey their connotative meanings and they manage only to convey the denotative meanings. The example below represents a 
74 Lexical Incongruity in Translations of American Political Speeches into Arabic

political speech by President George W. Bush entitled "Defending the War in Iraq".

Iraq, which once had the worst government in the Middle East, is now becoming an example of reform to the region. And Iraqi security forces are fighting beside coalition troops to defeat the terrorists and foreign fighters who threaten their nation and the world. Today, because America and our coalition helped to end the violent regime of Saddam Hussein, and because we're helping to raise a peaceful democracy in its place, the American people are safer. (Applause).

Ina al'arak aledhi kana lahu feema ma da 'sw' hukooma fee al shark al awsat, asbaha alaan namudhajan lil islah fee al mantaka. Wa ina qwat al amin al'akakiyya tukatil ila janib qwat al tahaluf litahzim al irhabiyeen wa al muqatileen al ajanib aldheena yuhadidoon biladahum wa al 'alam. Wa al yawm najid al sh'ab al 'mreeki akthar amanan, li'na 'merika wa bi musa'adat qwaat al tahaluf 'amalat 'ala al qadh' 'ala nidam sadam hussain al sarim, wa li'anana n'amal 'ala ihlal ni dam dimuqrati silmi makanahu. (Tasfeeq).

This segment is characterized by an excessive use of emotive items. The translator may choose to translate a lexical item with [+emotiveness] as opposed to [- emotiveness]. The italic items in the ST are highly emotive for the Iraqis and Arabs, i.e., they are emotive, evaluative and carry value-judgement. They have negative connotations

\footnotetext{
${ }^{1}$ Since the present study deals with the analysis and discussion of texts rather than mere sentences and for limitations of space, the extracts will be limited in their number. For this reason too, the original Arabic examples are deleted and only their transliterations are retained.
} 
for the Iraqis and Arabs as they reinforce the existence of the American occupation of Iraq . Therefore, the translator must be very careful in translating these lexical items in order not to sound offensive to his audience.

It goes without saying that the native speakers of a language have keen appreciation of the emotive meanings of words. Consequently, translators are faced with problems of how to cope with culture-specific expressions. A translator may be completely faithful to the ST, but the reader needs further explanation. In translating the lexical items in the above paragraph, the translator is not neutral and becomes involved by managing the text rather than only monitoring it. Shunnaq (1998: 41-42) indicates that managing a text emotively could happen in argumentative text types of which political speeches are common genres, but in expository texts the translator should only relay the text as it is and not mistranslate it by managing the situation.

\subsection{Hypotheses}

It is hypothesized that considerable linguistic and cultural differences exist between Arabic and English. There are many problems facing the translator of political discourse with respect to emotiveness, equivalents and connotations. It is assumed that the speeches delivered by President Barack Obama aim at rebuilding U.S. credibility in the Arab world, which was tarnished during the Bush era. Therefore, more positive connotations i.e., [+ emotive] of lexical items and less lexical incongruity in translating President Obama's speeches are expected than these of President Bush.

Moreover, it is expected that instances of emotive overtones which involve value judgments upon the meanings of certain lexical items (in the data of this study) as negative, positive or neutral are more natural in Arabic than in English. Incongruence in translating certain lexical items with emotive expressions is usually caused by 
76 Lexical Incongruity in Translations of American Political Speeches into Arabic

the negative and positive type. In addition, mistranslation of some highly emotive items for Arabs are expected in the data due to overlooking their emotional effect and connotative meanings.

Further, problems of emotiveness, lexical incongruity and culture (of which politics is a branch) need to be fully investigated and analysed. This would pave the way to devise strategies that help in achieving a successful and accurate translation of political lexical items. A CA of the semantics of political lexical items in this study would show whether the rendering of an English lexical item into Arabic is congruent or non-congruent. Finally, translators of political texts from English into Arabic ignore the effect their translation should achieve on the audience with respect to emotiveness and connotations and they focus only on the denotative meanings of the words and expressions in the text.

\subsection{Aims of the Study}

The study aims at analysing the linguistic and cultural problems involved in the translation of political lexical items with emotive overtones. It intends to $t$ investigate the effect of translating emotive terms in the TL and the role the translator plays in order to translate effectively. Showing instances of incongruence in translating certain lexical items in the data, describing how different translators can handle these problems, examining the adequacy of the translations of the sample texts in this study when dealing with highly emotive and non-congruent lexical items in Arabic and English, and comparing the results with these suggested by the writer of the present paper are among the other aims.

The study further endevours to explore the effect of CA by showing whether certain lexical items in two different languages share the same semantic features and associations that could highlight the possibility of their translation, and to which degree it tries to discuss the appropriateness of certain strategies for the 
translation of incongruent political lexical items due to the connotative meanings they express.

\subsection{Scope of the Study}

The present study is restricted to investigating emotive overtones and lexical incongruence in translation (not interpreting) from English into Arabic. It will heavily draw on argumentative discourse of political speeches as a text type for analysis and discussion. The sample texts are randomly selected on the basis of their emotive overtones from different online political speeches delivered by two American presidents, George W. Bush and Barak Obama, when addressing the Arabic and the Islamic World. The sample texts focus on the war on Iraq for the political sensitivity of other Middle East issues.

\section{Background}

Equivalence has always been described as the core of the whole process of translation. In fact, no translation can be done without taking equivalence into account. Thus, the central problem of translation-practice is that of finding TL equivalents. A central task of translation theory, on the other hand, is that of defining the nature and conditions of translation equivalence (Catford 1965: 21). Translation is a mode of communication where choices are further subjected to a principle of equivalence between a ST in one language and a TT in another. The term 'equivalence' most essentially designates the correspondence of effects, i.e., those of the original on the SL audience versus those of the translation on the TL audience (Farghal 1994: 57). 
78 Lexical Incongruity in Translations of American Political Speeches into Arabic

\subsection{Lexical Equivalence}

Zgusta (1971: 312) defines lexical equivalence as "a lexical item of the TL that bears the same lexical meaning of the lexical item of the SL." Such an absolute equivalence requires that the lexical meaning of the SL and TL words must be absolutely identical in connotation, and in their range of application, etc. But, such equivalence is rare, especially outside the domain of scientific registers. In fact, lexical meanings of the SL and TL lexemes are usually partly identical. These are called partial equivalents. Further, Nida (1979: 11) maintains that any single lexical item may have a number of different senses, but in most cases, each lexical item has a central meaning that serves as a 'root' from which other meanings may be derived.

\subsubsection{Types of Lexical Equivalence}

Snell-Hornby (1988: 20) endeavours to adopt an approach to equivalence to discuss the single lexical item. He suggests four types of this kind of equivalence. The first is one-to-one equivalence, which is also called as total or absolute. This type is usually achieved on the root level as in the example of universal lexical items and standardized scientific terminology. The second is one-tomany equivalence, which is also termed optional as in the equivalents of the Arabic word hadaf: objective, aim, goal, purpose, etc The other types are one-to-part of one equivalence, which is also termed as partial or approximate and zero-equivalence, which is usually encountered in culture-bound words as in the Arabic political words: jihaad, ridda, etc. The last types of lexical equivalence are particularly the subject of investigation in the present work. To these, certain strategies will be suggested where possible.

\subsubsection{Connotative Meaning}

Nida and Taber (1969: 91) indicate that the connotative meaning 
of a sign, which is called 'associative' or 'emotive', is "the aspect of the meaning which deals with our emotional reactions to words." Connotative meaning refers to the non-criterion properties of a word. It is associative, subjective and affective. Leech (1981: 12) defines it as "the communicative value an expression has by virtue of what refers to over and above its purely conceptual contents." According to Waard and Nida (1986: 146) connotative meaning consists of certain features derived primarily from the practical contexts in which such a term is used; including people who habitually use such expressions and the circumstances in which such words frequently occur. Newmark (1988: 16) maintains that "all texts have connotations, an aura of ideas and feelings suggested by lexical words (e.g., 'run' may suggest 'haste' and 'sofa' may suggest 'comfort')."

Nida (1969: 91) states that we not only understand the references of words, but also "react to them emotionally, sometimes strongly, sometimes weakly, sometimes affirmatively, and sometimes negatively." Unlike the conceptual meaning, the connotative is culture-specific. Different languages frequently articulate different connotations and associations of feeling, because of differences in cultural roots. As far as the political concepts are concerned, connotations play an important role in determining the word usage in certain contexts rather than another. For example, the words munadil and thawri have positive connotations in Arabic political culture, while those which are supposed to be their English equivalents, i.e., 'militant' and 'revolutionary' may have negative connotations.

Differences in connotative meanings are more salient when the lexical items are related to concepts of a higher emotional charge, e.g., political or religious concepts. Abdul Rahman (1997: 156) indicates that none of the connotations of the Arabic lexical items: Alwatan al Arabi, Al'uma alArabiya and Al qawmiya al Arabiya (which are highly emotive and of positive connotations) in English ('the Arab homeland', 'the Arab nation' and 'Pan-Arabism', 
80 Lexical Incongruity in Translations of American Political Speeches into Arabic

respectively) carry the same connotative or communicative value. The latter involves the concept of 'nationalism' which has a positive connotation in Arabic, but a negative one in English.

Arabic linguistic elements (words, phrases, etc.) are highly connotative, because Arabic has a continuous and uninterrupted linguistic usage and literary tradition for at least 3000 years. Therefore, many words have old and new denotative and connotative meanings. It is suggested that meanings, concepts and values, which are naturally transmitted by language, live longer in the Arab world (Al-Kasimi 1982: 12).

Lushin (1995: 191) adopts de Saussure and Abu Hatim Ar-Razi's approach in dealing with emotive meanings (referred to as echoic or associative) al ma'na al iha' $i$ in a text. She maintains that the use of a certain lexical item tends to produce emotive responses with other lexical items that do not occur in the same text. Rather, they are linked to this particular lexical item in terms of the cultural background and stored knowledge of an individual which varies from one person to the other. The followings are some illustrative examples in this respect:

jihad 'fighting'; taçhiya 'sacrifice'; shaja'aa 'courage'; ma'araka 'battle'; harb' war'; istishhaad; 'martyrdom'; silaah 'weapon'; mawt 'death'; jnood 'troops'; abtaal 'heroes'; thawra 'revolution'; risasa 'bullet'; m'adan 'metal'; 'rḍ' 'land'; qatil ' killing'; fidaa' 'sacrifice'; watan 'homeland'.

Omar (1982: 251-69) discusses that the major problem in translation from one language into another can be identified in trying to find an appropriate equivalent in the TL that matches the item of the SL. This presupposes that the two languages have (a) the same classification, (b) social and cultural backgrounds, (c) the same metaphoric and idiomatic and emotive expressions and (d) the 
same images, which seems to be impossible. Shunnaq (1993: 38) maintains that translating emotive expressions usually involves items which have only partial equivalents and items which do not have equivalents, which makes it necessary for the translator to struggle to preserve the emotive element in a certain language like Arabic, so as to achieve congruency. Omar (1982: 267) adds that the problem also lies in the fact that most traditional lexicons focus on what is so-called "main" or "major" (also called first, central or conceptual meanings), i.e., denotative - the actual representative of the main function of language ignoring the other essential aspects of meaning like:

1. The associative, minor, incidental to language, i.e., connotative meaning;

2. Echoic meaning;

3. Stylistic meaning and

4. Psychological meaning.

In this respect, Newmark (1981: 133) suggests that translators sometimes have to give precedence to emotive and affective elements in the SL over the informative or content elements if the context requires that. Hence, an Arab translator translating emotive lexical items into English should take this suggestion into heart (For more details, see Waard and Nida 1986: 147-48; Shunnaq, 1993: 4055 and Sirriyya, 1998: 103-10).

\subsubsection{Connotation and Communicative Value}

Taking the present period as an example, certain concepts could be analysed according to their communicative value, evaluative meaning, and connotations. Lakoff (1922: 221-271) points out that to be able to measure the communicative value and evaluative meaning of a concept or signified, its connotation in a given culture 
82 Lexical Incongruity in Translations of American Political Speeches into Arabic

with a certain historical period have to be the indicators. For relevance to the present investigation, it would be convenient to measure political terms and concepts according to their general connotation in Arabic and in English. The connotations of particular political concepts differ from one speech community to another according to the adopted political systems and the policy of their mass media, for instance, the word 'capitalism' has positive connotations in a capitalist state, while negative in a socialist state and vice versa.

Therefore, when translating, the connotation of each concept, it should be carefully considered to guarantee communication with the addressee. The symbol $(+)$ stands for positive connotation, $( \pm)$ stands for neutral, and (-) for negative, Aziz (1990: 60):

\begin{tabular}{|c|c|}
\hline Arabic & English \\
\hline \hline Shi'ar + & Slogan - \\
\hline Niḍal + & Struggle $( \pm)$ \\
\hline Jamaheer + & Masses - \\
\hline Librali - & Liberal + \\
\hline
\end{tabular}

In this connection, Shunnaq (1993: 47) also indicates that many Westerners usually associate jihaad with negative connotations such as 'fighting', 'Muslim's holy war', etc. The semantic components of jihaad and 'fighting' could be analysed as follows:

\begin{tabular}{|l|c|c|}
\hline \multicolumn{1}{|c|}{ Semantic Component } & Jihaad & Fighting \\
\hline \hline Fighting in God's cause & + & $?+$ \\
\hline Self sacrifice in the service of God & + & $?-$ \\
\hline Sacrifice of property & + & $?-$ \\
\hline Mere brutal fighting & - & $?$ \\
\hline Scholar's pen or wealth as forms of contribution & + & $?$ \\
\hline
\end{tabular}

From the above analysis, it seems clear that the English lexical 
item 'fighting' is an inadequate translation of the Arabic term jihad, since there is no word or expression in English which actually represents the emotive overtones of the original. The item jihaad links the struggle with faith. It is considered as a lexical gap by translators and the translation of jihaad as 'fighting' is consequently non-congruent.

Shunnaq (1998: 39-48) states that the translator may opt for translating a lexical item with (+ emotiveness) as opposed to (emotiveness). In a political speech, i.e., an argumentative text, a translator should make an excessive use of emotive vocabularies. The lexical items 'tragic' alm 'sawi; 'sad' almuhzin; 'overwhelming' alsahiqa, for instance, are highly charged with emotiveness, i.e., we react to them emotionally. Thus, a translation should attempt to convey the same emotiveness.

The emotive meaning of a lexical item pertains to the aura of the personal feelings it arouses in the text receiver. The lexical item could be pleasant to a certain receiver, but unpleasant to another. Roughly speaking, a lexical item would be received negatively, positively or neutrally by the text receiver. In addition, lexical items have emotive overtones which involve judgments for the meanings of certain lexical items as "negative," "positive" or "neutral" (Shunnaq 1993: 40). For example, 'martyr' shaheed, 'government' hukuma, 'fight/struggle' ni çal, 'soldiers'/ 'fighters'/ 'heroes' jnood / abtaal, 'army', 'armed forces' jeish / qwat musalaha are examples of the positive type; while 'dead', 'killed' amuaat / qatla; 'regime' ni d̦am , 'aggression' 'adwan, 'mercenaries' murtazaqa and 'gang' 'asaba are examples of the negative type.

\section{Fundamental Issues}

\subsection{Political Texts}

Political texts are texts of struggle to change the public opinions 
84 Lexical Incongruity in Translations of American Political Speeches into Arabic

(Fairlough 1995: 182). The field of political texts covers a variety of subjects such as military, activities, foreign policy, international law, war affairs, social problems, crisis, battles, uprising, riots, treatise signed, votes taken, celebration of victory and despotism. In fact, these subjects appear in newspapers, periodicals, magazines, pamphlets, because these media varieties constitute an integral part of political life (Lasswell \& Leites 1965: 9). Such varieties define the limits in which people think and discuss political topics.

A political text is the umbrella term covering a variety of genres. The characterisation of political texts can be based on functional and thematic criteria. Political texts are a part of and/or the result of politics and they are historically and culturally determined. They serve different functions due to different political activities. Their topics are primarily related to political activities, political ideas, political relations, etc. Further, in the majority of cases they are meant for a wider public (Schaffner 1996: 202).

Newmark (1988) quoted in Abdul-Rahman (1997: 200) states that political texts are full of abstract concepts, powerful connotation and ready-made clichés which are better to be called political jargons, such as freedom, socialism, liberty, equality, etc. These terms are used to give the feelings of loyalty. In fact, politics nowadays pervades every aspect of human thought and activities to a greater or lesser degree. Language as a medium through which many activities are conducted would certainly come under the influence of politics.

\subsubsection{The Genre of Political Speeches}

Each text of writing involves different linguistic features to adequately express the message through a proportionate style. Therefore, each text type requires specific skills, or as Crystal and Davy (1969: 173) point out that each type "from a linguistic viewpoint would be dealt with under the heading of other kinds of 
English, or would be too idiosyncratic to allow generalization."

Looking at political speeches from the functional perspective, they are not a homogeneous genre. Instead, there is a range of subtypes determined by the particular communicative situation, including the characterisation of the communicative partners (i.e. who is speaking to whom? when? where? why?). Based on these criteria, a discourse analysis can look into all levels and aspects of language, into pragmatics (i.e. the interaction amongst speakers and hearers), semantics (i.e. meanings, the structure of the lexicon), syntax (i.e. the internal organisation of sentences) and phonology/ phonetics (i.e. intonation, stress patterns, pauses) (Schaffner 1996: 203).

Reisigl (2008: 243) defines political speeches as structured verbal chain of coherent speech acts uttered on a special social occasion for a specific purpose by a single person and addressed to a more or less specific audience. In addition, speeches differ from each other in length, with respect to their occasion, their topic, their function (i.e., to persuade, threaten, promise, make rational arguments, etc), the speaker, their addresses, their form of presentation and degree of preparedness and with respect to their style and structure.

\subsubsection{The Language of Political Speeches}

Schäffner (1996: 201) indicates that any political action is "prepared, accompanied, controlled and influenced by language. We could easily add other verbs to this list, such as 'guided', 'explained', 'justified', 'evaluated', 'criticized"' Language is the principal tool of the politician and as such offers much in the way of linguistic analysis for the study of the power of syntax and lexis to persuade and motivate. Political speeches employ the many and various linguistic devices within their textual structure to argue and persuade effectively. Language is a powerful and emotive stimulant and the way a speech is constructed and delivered has been shown 
86 Lexical Incongruity in Translations of American Political Speeches into Arabic

over the centuries to have tremendous influence, both negative and positive. In addition, knowledge of method and intent are important in the ability of an audience to differentiate astutely between the two and avoid being either persuaded or motivated against their better interests or those of the public at large. Thus, the language used to persuade the people addressed as to how they should view events is a determining factor in a positive or negative response (UK Essays 2010).

A team of professional speech writers who have special skills in the use of persuasive language usually compose political speeches. Therefore, a political speech is not necessarily a success because of correctness of truth, but of presenting valid argument (Beard 2000: 18).With political speeches concerning real war, for instance, Charteris-Black (2005: 181ff) argues that the rhetorical strategy President George W. Bush used in one of his speeches was to describe the US as synonymous with the civilized world in contrast to Iraq and sometimes other Arab countries that were associated with terrorism and outlaw regimes. This illustrates how the US synonym interacts with the contrastive Iraqi one in terms of the features [+emotive] and [- emotive]. These features have different impacts on the audience of each of these cultures. Further, this reflects the importance of ethics and language if the leader wants to convince people of the rectitude of going to war (for more information see Haskett 2010 Lena 2009).

Thus, one man could at once unite, reflect and pacify those of a nation. In other words, the right words at the right time persuaded people to believe in the speaker's ethos and motivated them to react as the orator wished.

\subsubsection{Emotional Overload}

Emotiveness is one of the cultural problems which face the translator of English texts into Arabic or vice versa. Native speakers 
of a language have a strong appreciation of the emotive meanings of words. According to Shunnaq and Farghal (1999: 107) the emotive meaning of a lexical item refers to the emotional responses which that lexical item arouses in the text receivers. This response could be neutral, negative or positive in varying degrees. The intention of the author, the emotionality and the experience of the text receiver and the context of situation in addition to other factors influence the degree of emotiveness in language.

The tone of the TT should be determined by the TL stylistic norms, in order to secure naturalness. However, there is no rule in translation to refrain from the SL tone, provided that it is appropriate to the addressees' acceptability (Beaugrande \& Dressler 1981: 7-8). Thus, a competent translator permits no constraint by the SL tone and style. Duff (1981: 114) maintains that emotional overload usually manifests itself in argumentative texts which allow persuasion. Brooks and Warren (1970: 163) observe that in argumentative texts, writers either try to "win" over the addressee, or to "find the truth" for him. They state that in the former approach, the writer may appeal to the reader's reason or emotion. In the latter's approach, he tries to reach a conclusion which seems acceptable and reasonable. Palmer (1981: 36) observes that "in politics, particular words are often chosen simply for the effect they are likely to have ... words may have different emotive meanings in different societies." $\mathrm{He}$ (ibid: 61) adds that such words are used for persuading or influencing others. Hence, any exaggeration in the use of such emotive expression is considered as "emotional overload."

\section{Translation of Political Expressions}

Almost all varieties of language, including the political one, deal with metaphors, collocations, idiomatic expressions, emotive expressions, etc. A native language receptor may sometimes easily 
88 Lexical Incongruity in Translations of American Political Speeches into Arabic

perceive the communicative value and purpose of these which reflect experiences of his surroundings (cultural, social, economic, political and others). However, several difficulties arise when we set out to transfer that value and purpose to a different receptor that is already the product of different cultural settings. In particular, the remarkable feature of political terms is that they are value laden, i.e., they are judged as good, bad or neutral. This feature is closely related to the connotation of words.

Semantically speaking, the problem of word concept arises when there is a single term whose meaning is hard to define, because it is primarily determined by the cultural and linguistic context. Shunnaq (1993: 48) indicates that the emotive function of a language involves changing the emotive state of the receptors. That is why politicians manipulate language to win their audiences' emotive approval. For instance, the following example extracted from a political speech delivered by President Saddam Hussein on the anniversary of the Power aggression on January 17, 1999 is loaded with emotive words and expressions (almansore. net 2010):

\section{(3)}

... Wa Jaa' al Gharb must'amiran, mughtasiban, mu'atadiyan, nahiban khayraat al naas, wa bidhalika izdaad al naas ghaman wa haman wa fuqran 'ala ma kanoo 'alayhi, wa saroo yarzahoon tahta a'aba' i,̣fiya, ratabaha 'alayhum al ihtilal al 'askari wa al isti'amari, wa lam yajloo al Gharb 'an al diyaar, alati ihtalaha 'askariyan wa ist'amaraha, ilaa b'ada ta dhiyaat taa'ila li abna'iha... .

... the West came as a colonist, usurper, aggressor and a plunder of the people's resources. Therefore, the people became poorer and more worried and distressed than they were, and now they are languishing under the weight of additional burdens, forced on them by the colonial military 
occupation. The West did not leave the land which it had occupied and colonized by its military forces, only after enormous and great sacrifices of its sons [people] (-Tr)

As it appears in the above extract, a general characteristic of Arabic political terminology is its being charged with high emotive meanings, which are difficult to translate into the TL with the same effect they have in the SL. There is often more sensational power behind such terms than the meaning they intend to carry. This is a purely distinct feature that figures high in Arabic political texts and plays a very low profile in the TL. The principal carrier of emotiveness in this text is indicated by the negative connotations (i.e., emotive overtone in Arabic) of the lexical items such as: must'amiran 'colonist'; mughtasiban 'usurper'; mu'atadiyan 'aggressor 'and the others in this text like: nahiban; khayraat al naas; ghaman; haman; fuqran; 'aba' idhafiya,; al ihtilal al 'askari wa al isti'amari; al Gharb; al diyaar,; 'askariyan; ist'amaraha; tadhhiyaat taa'ila; li abna'iha. The TL equivalents of these words and expressions (e.g., the West; a plunder; people's resources; poorer; more worried and distressed ;additional burdens; the colonial military occupation; the land; occupied and colonized; military forces; enormous and great sacrifices; sons) do not have the same emotive effect on the TL audience. Therefore, they do not achieve the required communicative value of the $S T$.

\subsection{The Translator of Political Texts}

Since Arabic political discourse is charged with emotive connotations caused by political bias, the translator should be alert and careful in the selection of lexical items and their connotative meaning. However, in translation, the denotative meaning is usually rendered while the connotative meaning is frequently lost. Translators should also take the cultural differences involved into 
90 Lexical Incongruity in Translations of American Political Speeches into Arabic

consideration, such as the emotive tone of Arabic political discourse as compared to English.

When discussing the translation of political texts in the wider sense, the activity of translation itself is characterised as being related to politics. Alvarez and Vidal (1996: 2) define translation in general as a political act, since translation is culture bound and has to do with the production and ostentation of power and with the strategies used by this power in order to represent the other culture. They argue that all translators' choices, from what to translate to how to translate, are determined by political agendas. Translators, therefore, are highly influenced by the political context and this determines whether their translation of a political text will emotively be negative or positive.

Shiyab (2006: 63) maintains that in order to guarantee effective translation, the translator has to ensure that both the ST and the TT convey the same message. This could be achieved when the translation accurately conveys and expresses the meaning of the ST and when the translated text sounds natural to the native speakers of the TL as if it has originally been written in that language. Yet, the outcome of translation varies due to many factors. Translators of different linguistic and cultural backgrounds do not produce similar versions of the ST. In other words, the same SL text has different TL translations when performed by different translators representing different backgrounds. Therefore, translators of political texts should be aware of the cultural dimensions and the political environment of the SL and the TT, in addition to the degree of emotive sensitivity of the TL audience. This is an essential prerequisite to the successful rendition of the text and to avoid any possible offence to the TL readership.

\subsection{Lexical Incongruity in Translation}

In fact, a deep understanding of the political culture of the SL is 
essential if the lexical items are to be appropriately translated into the TL. Arabs give the word a heavy weight as the deed; therefore, their language has developed a rhetoric which addresses the heart before the mind. By comparison, English people often tend to use language to express a calm confidence, which ought to be proved by deep rather than the firey language. It is this thundering style which has made Arabs appear to be too emotional. Shunnaq (1993: 48) points out that there are some lexical items which are highly emotive in the context of "the Palestine tragedy" such as alintifa da 'uprising', alhijaara 'stones', jeel alhijaara 'generation of stones', $m$ 'arakat alhijaara 'battle of stones', alnaar 'fire', altahadi 'confrontation', aljareema 'crime', alth'r 'revenge' which all have more than their denotative meanings. They have a positive emotive effect in Arabic, while their English counterparts have not and are actually non-congruent.

In this connection, Shunnaq (ibid.) indicates that the rendering of the lexical items kibriya' and karama into dignity and pride is incongruent due to the connotative meaning each of which involves. Both are symbols of ethics upheld by the Arabs as supreme values in their lives. Consequently, rendering them equivalently into English could be considered as "an unattainable task if not impossible."

\begin{tabular}{|c|c|}
\hline Karama & Kibriya' \\
\hline \hline+ dignity & + pride \\
\hline+ self-respect & + grandeur \\
\hline+ self-esteem & + glory \\
\hline+ noble-heartedness & + magnificence \\
\hline+ high-mindedness & \\
\hline+ nobility & \\
\hline+ honour & \\
\hline
\end{tabular}


92 Lexical Incongruity in Translations of American Political Speeches into Arabic

Similarly, emotive vocabularies have also been noticed in English texts with [+ emotiveness] or [- emotiveness] when rendered into their Arabic counterparts. A translator should be aware that some lexical items could lose their emotive overtones when rendered into Arabic. For instance, the word 'rat' in English could be used negatively to refer to a person who is 'coward', whereas its equivalent jur dh in some Arab countries cannot be used to convey the same connotation (Shunnaq 1993: 40). However, some emotive expressions could be congruent as in: 'stupid as an ass' which its counterpart in Arabic is ghabi kalhimaar, as well as the items 'massacres' majazir, 'slaughters' madhabih where the first also implies 'butcheries' and the second has the meaning 'massacres' too. These items are highly emotive, evaluative and carry valuejudgment. They have negative connotations in both English and Arabic as illustrated in the following extract taken from a speech delivered by Anti Zionist Orthodox Jews at the "Emergency Protest to stop the Massacre in Gaza" Rally, Rockefeller Center in New York City, December 27, 2008 and again at a protest in London on December $28,2008$.

To the governments of the world, it is not through your support of the Zionist regime - the State of "Israel", that the Jewish people are being helped! On the contrary, this tragic historical mistake has led to the killing of Arabs and Jews alike. The governments of the great powers, by supporting the State of "Israel" are not only harming the Palestinian people but they are also unwittingly contributing to the growth of hostility towards Jews worldwide!

Here, the items 'support' da'im; 'Zionist regime' nidam Sahyooni ;'State of Israel'; dawlat Israel ; 'tragic historical mistake' al khata' altarikhi alma'sawi; 'Killing of Arabs and Jews' Qatil Al 
Arab wa Al Yahood; 'great powers' alqiwa al'adhma ; 'harming' $Y u$ 'dhi ; 'Palestinian people' alsh'ab Al Falasteeni and 'growth of hostility'nimoo al 'ada' are highly emotive in the Arab consciousness, the Anti Zionist Jews and for the worldwide human conscious as they refer to occupation, killing and tragic situations carried out by the governments of the great powers against the people of Palestinians. Thus, what is important for the translator is that he must be aware that the translation of these terms should preserve the emotive element in Arabic so as to achieve congruency. From the same article, the following extract is chosen:

We must tell the world that self rule, sovereignty and ALL the rights of the Palestinian people, must be restored throughout historic Palestine! This is a requirement of Jewish ethics and values! Jewish justice demands the return of the Palestinian refugees to their homes, towns, villages and cities throughout Palestine! Tell the world, loudly and clearly, that you support Palestinian statehood over the ENTIRE Holy Land - not despite your Jewish identity, but because of it.

All the lexical items and expressions in the above extract like self rule, sovereignty, the rights of the Palestinian people, historic Palestine, Palestinian refugees, homes, towns, villages and cities, Palestinian statehood, Holy Land; all have the following meanings: alqura, albaladiyat, diyarhum, alaji'oon al Falastiniyoon, Falastin altareekhiya, huqooq alsh'ab al Falastini, alsiyada, alhukum akdhati, al'rd almuqadasa, aldawla alFalastiniya and almudun respectively. These are all highly emotive to the Arabs and the AntiZionists around the world. Among these, 'Jewish ethics and values', 'Jewish justice' and 'Jewish identity' (i.e., alqiyam wa alakhlaq alyahoodiya, al 'adala alyahoodiya and alhawiya alyahoodiya) have neuter emotive meanings in Arabic, while for the Jews and Anti 
94 Lexical Incongruity in Translations of American Political Speeches into Arabic

Zionists they have positive emotive values. Consequently, for the identical agreement on the emotive values of the meanings of words in this text in both the SL and the TL, a congruent Arabic translation of this text is possible.

\subsection{Emotive Connotations as a Means of "Managing" in Translation}

Shunnaq (1993: 57) states that translators can heighten the emotiveness by using expressions with suitable connotations. He confirms that receivers of "managed" translation (associated with subjectivity and emotiveness) versions are generally in danger of being misled in conduct by an excess of feeling which is usually injected in some lexical items. In fact, many translations are designed not to transfer denotative meanings, but to sway the TL receivers, i.e., they use connotative words rather than denotative ones to manage the text. In other words, they use certain lexical items for their emotional overtones rather than for honesty and equivalence. For instance, in certain radio stations, they render the Arabic word fida' $i$ as 'terrorist' rather than 'freedom fighter' to reflect unfavourable connotations. Other lexical items which can be portrayed as "desirable" or "undesirable" are qala 'said' instead of ida'a 'claimed'; intifa d̦a 'uprising' instead of idtirabaat madaniya 'civil disturbance', Wazir Alharb Al Isra 'ili 'Israeli Minister of War' instead of Wazir Aldif'a Al Isra 'ili ' Israeli Defense Minister', etc.

The notions of "managing" and "monitoring" introduced into text linguistics by Beaugrande and Dressler (1981: 163) and Beaugrande (1984: 39) express the instances in the previous paragraph and seem well suited to the present argument. They indicate that

if the dominant function of a text is to provide a reasonable unmediated account of the situation modal, situation 
monitoring is being performed. If the dominant function is to guide the situation in a manner favourable to the text producer's goals, situation management is being carried out.

Thus, a translator, in such cases, is considered as biased, because he chooses words that solely serve his own purposes. It is, therefore, recommended that a translator should be trained to be able to render fully and efficiently the relevant features of managing.

\subsection{Methods and Strategies of Translating Emotive Lexical Items}

In fact, serious efforts have been expended in an attempt to render emotive lexical items. In this connection, most of the strategies adopted aim at conveying meaning through transliterating annexed with either footnote or a commentary, literal render, i.e., utilize formal equivalent and attach on the spot with a commentary elucidating what these concepts essentially refer to, paraphrasing, translation couplet or triplet (for more details concerning strategies of translation see Sirriyya 1998: 22-40, 103-109).

Political texts abound with cultural concepts and emotive expressions. The present study, therefore, focuses on the implications relevant to the translation of lexical items that occur in political speeches for this genre of political texts is loaded with emotive implications.

According to Reiss (2000: 38-40), political speeches is a genre of a text type referred to as "appeal-focused texts." These texts are distinctive in "always presenting information with a particular perspective, and explicit purpose, involving a non-linguistic result." They are texts in which the element of appeal is dominant (e.g. propaganda and other texts with political features and purposes). Concerning the translation method appropriate for texts of this type, it is essential that in the TL, the same effect be achieved as the 
96 Lexical Incongruity in Translations of American Political Speeches into Arabic

original in the SL (ibid: 41). This means that the translator has to depart more from the content and the form of the original and focuses on the extra linguistic aspect of persuasion in the text. It goes without saying that any such changes from the ST should not be regarded by the critic as violating the principle of fidelity. Regarding the translation of lexical elements, the standard must be "adequacy." A kind of mirror-image literal accuracy so often demanded in the TL cannot serve as an objective criterion because the vocabularies of any two languages (with their structural and conceptual differences) simply cannot coincide completely. Therefore, the translator should have demonstrated competence in dealing with special idioms, false friends, metaphors, proverbs, connotations and emotive expressions, etc. for an adequate translation on the lexical level. For appeal focused texts an equally idiomatic metaphor of similar value or significance must be created in the TL (ibid: 58-9). This also applies to the translation of the other varieties of lexical expressions like these with the emotive overtone.

In the present study, the preferable procedure to render political lexical items from English into Arabic is in terms of CA, i.e., the sense of the lexical item thought of as being emotive overtone, should be componentially analysed to enable the translator choose, depending on the context, the most relevant and adequate sense.

\subsubsection{The Use of Componential Analysis in Translation}

$\mathrm{CA}$ is a semantic theory which claims that all lexical items can be analysed by using a finite set of components which may be universal (Crystal 1985: 62).

However, Newmark (1988: 114) points out that CA in translation is not the same as CA in linguistics. In translation, the "basic process is to compare a SL word with a TL word which has a similar meaning, but is not an obvious one-to-one equivalent, by 
demonstrating first their common and then their differing sense components." He maintains that normally the SL word has more specific meaning than the TL word, and the translator has to add one or two TL sense components to the corresponding TL word, in order to produce a close approximation of meaning. Moreover, the sense components of a lexical unit may be referential and/or pragmatic. In general, a SL word may be distinguished from its TL counterpart in the shape, size, composition and function of its referent. On the other hand, they may differ with respect to their cultural context and connotations, period, social class, usage, degree of formality, emotional tone, etc. Finally, a SL word may be distinguished from a $\mathrm{TL}$ in the pragmatic effect of its sound composition.

Newmark, (1981: 27) indicates that lexical translation is more complicated than the discussion of lexical meaning. He adds that any bilingual dictionary appears to imply that most SL words have precise TL equivalents. The translator knows that this is not so, even before words are related to their context, they are related to reference and their idiolect concepts. On the contrary, most SL words have a variety of separate, contiguous, overlapping, inclusive or complementary sense, each of which consists of sense components. Since both the equivalent words and their senses are differently arranged in the TL, translation may be said to consist lexically of a transfer not of senses, but of sense-components. The translator has to split words or word series into components before transferring them and then relate them to context in the TL.

The components of any word a translator will require to use depend on: (a) the importance of the word in the context and (b) the requirement for brevity, i.e., decreasing the number of words and increasing the number of meanings. Here, translating the SL words may suffice in rendering all the meanings in certain instances (Sirriyya 1998: 79). Most commonly, the translator will analyse a word contextually, thereby dealing with one sense of the word and thereby restricting its TL sense components. Normally, the translator 
98 Lexical Incongruity in Translations of American Political Speeches into Arabic

carries out CA only on a word of some significance in the TL text which cannot adequately be translated one-to-one (Newmark 1981: 20;1988: 115).

The ordering of emotive before factual and functional before descriptive meaning is generally valid in translation. In addition, the pragmatic component of many words consists primarily in their positive or negative connotations. Shunnaq (1993: 51) points out that a CA of two lexical items would show that the word alsalam in the greeting Alsalamu Alaikum has much wider associations and signification than its English counterpart 'peace', as illustrated in the following table:

\begin{tabular}{|l|c|c|}
\hline \multicolumn{1}{|c|}{ Semantic Feature } & Salam & Peace \\
\hline \hline Free from unpleasant elements & + & + \\
\hline Soundness (as in the word Saleem) & + & $?$ \\
\hline Salvation (as in the word Silm) & + & $?$ \\
\hline Salutation & + & - \\
\hline
\end{tabular}

Consequently, the rendering of the Arabic lexical item Salam into English 'peace' is non-congruent as the Arabic looks more connotative.

Hatim \& Mason (1990: 57) see pragmatics as a dimension of context, which "builds into the analysis values relating to the ability to do things with words." They distinguish pragmatics, semiotics and speech acts as the dimensions of context. Pragmatics goes beyond the boundaries of words and sentences towards the context and accounts for the intended meaning. Al-Najjar (1984), quoting Time Magazine (October 25, 1982: 49), notes that the U.S. cover name "Rapid Deployment Force" is officially redefined in Arabic as "Rapid Intervention Force":

For two years after the Rapid Deployment Force was created the official Arabic translation for the name could 
have been understood to mean "rapid intervention force." That is exactly the connotation Washington wants to avoid.(78)

Therefore, the difference is not attributed to mistranslation, but to pragmatics which has bearing on the meaning. A pragmatic approach to any text can provide the addressee with the feel and sense of the content, i.e., to capture the spirit of the text, since pragmatics involves the connotative meaning, because it expresses the "communicative value an expression has ... over and above its purely conceptual content." (Leech 1981: 14).

Further, the use of a CA applies also to the translation of cultural words that the readership is unlikely to understand. Even though the CA is accompanied by an accepted translation, transference, functional equivalent or cultural equivalent and so on, it will depend on: (a) the particular text type, (b) the requirements of the readership on the client and (c) the importance of the cultural word in the text (Newmark 1988: 123-4).

\subsubsection{Componential Analysis and the Translation of Lexical Items of American Political Speeches}

Newmark (1988: 132-4) sees the use of CA in translation as a flexible, but orderly method of bridging the numerous lexical gaps both linguistic and cultural, between one language and another. Nevertheless, it will tend to "over-translate" in its fight against "under-translation," i.e., the use of synonymy. Moreover, it is likely to be more economical than paraphrase or definition. He (138-9) maintains that whilst CA is indispensable in lexicography, it has applications to translation. Newmark believes that the role and use of CA in translation is very important and that it is of a greater use to the translator. Some of the main uses of CA for the translator can be listed below (Newmark 1981: 30): 
100 Lexical Incongruity in Translations of American Political Speeches into Arabic

1. To translate a SL word into two or more TL words by distributing its semantic components over a large TL area.

2. To expose and fill in gaps in the TL lexis, due to cultural distance between SL and TL, in the same semantic field.

3. To explain cultural differences between one word with one common main component, but different secondary components in SL and TL.

As it has been mentioned before, Arabic is loaded with expressions of cultural and religious connotations. Whether translating a text from Arabic into English or vice versa, this will result in problems in translation due to cultural gaps mainly. The sample texts in this study represent political language as a register in political texts selected randomly from the speeches of two American Presidents, i.e., the former Mr. George W. Bush and the current Mr. Barack Obama. The two Presidents have different political stands, standpoints, policies and political opinions towards various Islamic and Arabic issues. It is said that Obama wants to improve the American image in the Islamic and Arabic world especially in the Middle East that the American military occupations and interventions in time of his predecessor Bush have shown and the role they have played in shaping anti-American sentiments in the region.

However, commenting on an article entitled "Obama, Arab \& Muslim Opinion and Narratives: Thoughts \& Comments" Kal (2009) argues that the American policy is not designed to deliberately oppress or kill Muslims, but this simply happens for geo-strategic reasons rather than ideological ones. In addition, Arab public opinion is disappointed with Obama. This is not because he has not lived up to his predecessor's commitment to democracy and reform. Rather, the American policies towards Israel and the Palestinians, the invasion of Iraq, Abu Ghraib, Guantanamo and the Global War on Terror, and other deeply unpopular Bush administration policies 
badly undermined their credibility. He adds that Obama should deliver on his promises to the Muslims and Arabs and he should not abandon them. There is no vindication of the Bush administration's policies here, only frustration at his successor's inability to rapidly reverse them. Further, despite a great start on reframing relations with the Islamic world, a lot clearly still needs to be done. Kal finally maintains that

there is no altruism in American Middle policy regardless of what president carries it out. There will be Arabs disappointed with American policy in any case, because that policy is designed to suit and serve American interests and nobody else's. ... Bush's rhetoric was plainly disingenuous for many Arabs; Obama's has been not much more, though less so because of the power of his ideas than because of his personal aura and good will for not being Bush. ... Bush policy has ... caused much misery and disorder. It is not easy clean up so large a mess.(ibid)

Since many translation theorists have confirmed that the translators of political texts should be aware of the cultural dimension, the emotive aspects and the political context of both the SL and the TL in order to translate the text adequately, the researcher finds it necessary to shed light on the American political stand and policy in the Middle East. This will determine the rendition of the political lexical items in the sample texts in this study to have the feature [+emotive] or [-emotive] depending on the context that reflects the American political standpoints and policies towards the Muslims and Arabs. Therefore, the translators of the American speeches into Arabic should permit no constraint by the SL tone and style. They should manage the text emotively according to the needs, feelings and attitudes of their readers in order for their translation of the sample texts to sound adequate. 
102 Lexical Incongruity in Translations of American Political Speeches into Arabic

Thus, before analyzing and discussing the translations of the sample texts in this study, it is worth giving the audience a background about the American policy towards the Middle East. Many Arabs have been unhappy with Bush's conduct in the war on terror, his handling of the war in Iraq, his biased handling of the Palestine-Israel conflict and there is an extra dissatisfaction with his policy towards the Muslims and Arabs in general. On the other hand, the majority of the Americans are aware of the United States' need to a real change in its foreign policy that removes the relics of the damage that was caused by the Bush Administration and the Neo Conservatives in its reputation, its interests and international status. Therefore, El Solh (2009: 2-3) believes that it is necessary to emphasise that interest of President Obama's Admiration in the Islamic world is a valid and sound orientation and that it will lead to improving the United States' relations with millions of Muslims in the world. Moreover, this improvement will, however, stay limited and vulnerable if it is not accompanied with active efforts to remove reasons of tension with the Arabs in particular. President Obama directed an address to the Arabs saying that his Administration is ready to establish a relationship with the Arab world that is based on a new partnership and mutual respect (For more information see Lynch 2009).

As far as translation of the sample speeches is concerned, it is expected they show instances that reflect differences in the emotive aspects and connotations between the SL (English) and the TL (Arabic). So, it is very likely that negative views of the US in the Islamic and Arabic world are the result of a sense that American policy has been bad for them in recent years especially in time of President Bush. These have an effect on the translation of the ST and can be given the features [+ emotiveness] or [- emotiveness]. Further, instances which may lead to incongruity in translation are signalled and discussed too. The procedure to be followed in the analysis, discussion and comparison of the sample political speeches 
in this study involves, first, identifying the lexical items in each sample text that show different emotive overtone in English and Arabic. Second, it seeks to assign the features [+emotive] or [emotive] to each meaning of the lexical item in both the SL and the TL by means of CA procedure. This step is based on listing all the possible semantic components of a particular lexical item taken from the Oxford English Dictionary (OED). The symbol (?) refers to a meaning that is irrelevant completely to a given context. Third, the paper will explain the assigned emotive meanings and the semantic features of a lexical item according to its linguistic and cultural implications in the SL and the TL and suggesting a typical translation of the text based on the variations in the political context, policies, political stand and standpoints between the two languages. Fourth, it will compare two suggested translations of each sample text and a model translation provided by the researcher taking into consideration whether or not each of the translators (who are completely unaware of the subject matter of the study for achieving the utmost objectivity) has translated the text with respect to its emotive values in the TL and their effects on the TL audience. In the model translation of the text, the researcher only gives the right emotive meaning of a particular SL political lexical item that sounds appropriate and not offensive to the TL audience, i.e., Muslims and Arabs.

\subsubsection{Presidents Bush and Obama's Policy: Background}

Before starting a CA of President Bush and Obama's political speeches and their translation into Arabic, it is important to give the readers of the present study a brief background on the public opinion in the Muslims and Arabs world in the Middle East about the two Presidents' policies. Kuhiwczak \& Littau (2007: 144) emphasize the importance of political background knowledge or lack of such knowledge on the part of translators for text comprehension and adequate translation. According to Bassnett 
104 Lexical Incongruity in Translations of American Political Speeches into Arabic

(1980/1991: xv), the translator who takes a text and transposes it into another culture needs to consider carefully the ideological implications of that transposition.

Among Arabs and Americans, there is an extra dissatisfaction with George Bush's policy towards war in Iraq, biased handling of the Palestine-Israel conflict, his treatment of Arab and Muslim immigrants through the Patriot Act and civil liberties problems since 9/11and the war on terror. He failed the Americans, Arabs and Muslims with his policy against human rights, foreign policy and the economy (Zughbi 2010).

In June 2009 US President Barack Obama delivered a historic speech at the University of Cairo in which he sought a new beginning between US and Muslims and Arabs. President Obama's speech seems as a good start and an important step towards a new American policy and even radical groups such as Hamas praised his address as a positive shift in U.S. attitude and tone. President Obama aims to repair ties with the Muslim world that have been strained under his predecessor President Bush. He insisted Palestinians must have a state and said continued building of Israeli settlements in the West Bank is not legitimate. He assured the Muslims and Arabs that the U.S. would pull all it troops out of Iraq by 2012 and promised no permanent U.S. presence in Afghanistan. Therefore, many people have hope in the new American administration. (Al Baik 2009 and Arab world sees positive shift in Obama speech 2009).

However, many others believe that they would never trust Obama because he is just an employee in the US administration and his speech which he delivered in Cairo is just what the US needs at this moment. They think his speech is just a public relation exercise with governments in the region. Consequently, Arab intellectual reaction to Obama's address fell on a broad spectrum ranging from hopeful and inspired to critical and unimpressed. They want him to turn his words into action. In other words, apart from the justifiable disappointment of democratic activists in the Arab world, the 
realization of promises in Obama's speech will depend entirely on deeds. What Obama has said is beautiful prose. All these leaders over the years have said beautiful words, but they have no effect on the ground. People will have to wait and see (Al Baik 2009; Arab world sees positive shift in Obama speech, ibid).

\subsubsection{Componential Analysis of Selected American Political Speeches}

Here, selected extracts taken from the political speeches of President George Bush and President Barack Obama addressing the Muslim and the Arab world constitute the sample texts in this study. The subject of the sample texts focuses on the American-Iraqi conflict merely for the political sensitivities of the other political issues. Each text is chosen with respect to the highly emotive political words and expressions it contains. For the limits of space, as more than three or four lexical terms in each text are componentially analysed, only five examples culled from the political speeches of each president represent the data in this study. It is worth mentioning that the researcher tries to achieve the highest degree of objectivity without being biased to any political standpoint. She only reflects the view point of the translator that matches the political stand of his audience - the people to whom he belongs.

First the sample texts representing the political speeches of President G.W. Bush are analysed and discussed. Then, these of President B. Obama are given.

Operation Iraqi Freedom was carried out with a combination of precision and speed and boldness the enemy did not expect, and the world had not seen before. From distant bases or ships at sea, we sent planes and missiles that could destroy an enemy division, or strike a single 
106 Lexical Incongruity in Translations of American Political Speeches into Arabic

bunker. Marines and soldiers charged to Baghdad across 350 miles of hostile ground, in one of the swiftest advances of heavy arms in history. You have shown the world the skill and the might of the American Armed Forces.

(G.W. Bush, May 1, 2003)

In (6), most of the italicized lexical items have different emotive overtones in English and Arabic. In addition, while one lexical item has the semantic feature [+ emotiveness] in one language, it has [emotiveness] in the other. For example, the three nouns precision and speed and boldness have the feature [ + emotiveness] for the Americans and the Coalition Forces, but for the Iraqis it has the opposite feature , i.e., [- emotiveness] as the American attacks were, in fact, not precise on many occasions and killed hundreds of innocent Iraqi families, women and children at their houses. This text, in fact, is loaded with similar negative emotive terms in the Iraqi, Muslim and Arab consciousness [- emotiveness], while they do not have such an effect at all for Bush and his allies [+ emotiveness].The lexical items like: 'operation', 'distant bases', 'ships', 'planes', 'missiles', 'destroy', 'divisions', 'strike', 'bunker', 'marines', ' soldiers', 'advances', 'heavy arms', 'skill', 'mighty', and 'American Armed Forces' are all emotively positive for the Americans and their allies, while they are negative for Iraqis and Arabs as they are associated with the severe / brutal American aggression on Iraq.

It could also be clear from the above example that the Arabic lexical items huriyat, 'adoo and ' $r$ d mu'adiya are inadequate translations of the English words 'freedom', 'enemy' and 'hostile ground' respectively. This is because the Americans have invaded and occupied Iraq in 2003 and it is not a free country ever since .Moreover, its land is not hostile, but the occupied forces have shown much hostility and aggressiveness to this land and its people. The word hyriyat has a negative connotation for the Iraqies, while 
its English counterpart 'freedom' has a positive one. In addition, the words 'adoo and ' $r$ l mu'adiya have negative connotations [emotiveness] for the Iraqis and Arabs; while their English counterparts 'enemy' and 'hostile ground' have positive emotive implications for the Americans and their allies .Therefore, the translator should not render them so; he should rather focus on more emotively positive renditions of these lexical items [+emotiveness]. Consequently, no wonder why the translation of 'freedom' into huriyat, 'enemy' into 'adoo and 'hostile ground' into ' $r d$ mu'adiya are non-congruent in this context. The strategy of substitution, then, could be used in this respect, i.e., to substitute huriyat by ghazoo 'invasion' or ihtilal 'occupation', 'adoo by al jaysh wa al sh'ab al 'Araqi 'Iraqi Army and people' and ' $r$ d mu'adiya by al'radi al'Araqiya 'Iraqi ground' or 'beloved homeland'. These substitutes reflect how the Iraqis feel towards their country and armed forces and how they stand against the invasion of their ground. A translator's decision here is based on a careful assessment of the communicative function of the source-culture element and of the communicative situation in which he finds himself vis-à-vis his receivers. In this sense, Toury (1987: 4) indicates that translation should not be regarded as a mere reconstruction of the ST, but as the production of "the text in a target setting for a target purpose and target addressees in target circumstances." Table 1 summarizes the semantic components of the aforementioned lexical items.

Table 1. Componential Analysis of the Connotations of the of 'Freedom' and 'Huriya'

\begin{tabular}{|l|c|c|}
\hline \multicolumn{1}{|c|}{ Semantic Components } & Freedom & Huriya \\
\hline $\begin{array}{l}\text { Exemption of release from slavery or } \\
\text { imprisonment; personal liberty }\end{array}$ & + & - \\
\hline Liberation from the bondage of sin & $?$ & $?$ \\
\hline Exemption from arbitrary, despotic or autocratic & + & - \\
\hline
\end{tabular}


108 Lexical Incongruity in Translations of American Political Speeches into Arabic

\begin{tabular}{|l|c|c|}
\hline \multicolumn{1}{|c|}{ Semantic Components } & Freedom & Huriya \\
\hline \hline control, independence, civil liberty & & \\
\hline $\begin{array}{l}\text { The quality of being free or noble, nobility, } \\
\text { generosity, liberality }\end{array}$ & $?$ & $?$ \\
\hline $\begin{array}{l}\text { The state of being able to act without hindrance } \\
\text { or restraint, liberty of action }\end{array}$ & $?+$ & $?-$ \\
\hline $\begin{array}{l}\text { The quality of being free of control of fate or } \\
\text { necessity; the power of self determination attributed } \\
\text { to the will }\end{array}$ & + & - \\
\hline Readiness or willingness to act & $?+$ & $?-$ \\
\hline Boldness or vigour of conception or execution & $?+$ & $?-$ \\
\hline $\begin{array}{l}\text { Capability of motion. the state of not being } \\
\text { affected by a defect or disadvantage }\end{array}$ & + & - \\
\hline $\begin{array}{l}\text { Exemption from a specific burden, charge or } \\
\text { service }\end{array}$ & $?$ & $?$ \\
\hline A privilege possessed by a city, corporation, etc. & + & - \\
\hline
\end{tabular}

Similarly, the word 'enemy' in this context is packed with negative connotations [-emotiveness] for the Iraqis who did not declare war on America or the Western world, but the country and its people have aggressively been invaded by the Americans and the Coalition Forces. So, only for President Bush and his allies this word has a positive connotation [+ emotiveness] to justify their war against the country. Thus, to the Iraqis and Arabs, the word 'enemy' is offensive and should be substituted instead by 'Iraqi Army and people' who were fighting for the freedom of their country against the American invaders and their brutal attacks. The semantic components of 'enemy' and 'adoo could be analysed as in Table 2: 
Table 2. Componential Analysis of the Connotations of 'Enemy' and' Al jaysh wa al sh'ab al 'Araqi'

\begin{tabular}{|l|c|c|}
\hline \multicolumn{1}{|c|}{ Semantic Components } & Enemy & $\begin{array}{c}\text { Al jaysh } \\
\text { wa al } \\
\text { sh'ab al } \\
\text { 'Araqi }\end{array}$ \\
\hline $\begin{array}{l}\text { One that cherished hatred that wishes or seeks to } \\
\text { do ill to another }\end{array}$ & - & + \\
\hline An adversary, antagonist, opponent & - & + \\
\hline $\begin{array}{l}\text { One belonging to a hostile army or nation ; an } \\
\text { armed foe }\end{array}$ & - & + \\
\hline The hostile force & - & + \\
\hline Adverse, hostile, ill-disposed, unfriendly & - & + \\
\hline
\end{tabular}

The noun phrase 'hostile ground' which literally refers to ' $r d$ l mu'adiya is highly emotive with negative connotation for the Iraqis [- emotive], but it is not so for the Americans and the Coalition Forces where it has a positive connotation [+ emotive] to justify war on the country and achieve their aims there. In this context, it is associated with invasion, brutal war and killing and all types of violence against the innocent Iraqis and their homeland. Therefore, it should not be rendered so. For the Iraqis and Arabs in general, the word 'hostile ground' should be rendered as 'Iraqi ground 'which is a more positive connotation [+emotive] as it is associated with the Iraqi dignity, country honour and sovereignty. Thus, translators should take this point into consideration and substitute 'hostile ground' by 'Iraqi ground' in this context. The semantic components of 'hostile' mu'adiya and 'Iraqi ground' al'radi al Araqiya could be seen as in Table 3: 
110 Lexical Incongruity in Translations of American Political Speeches into Arabic

Table 3. Componential Analysis of the Connotations of 'Hostile' and' Al'radi al 'Araqiya'

\begin{tabular}{|l|c|c|}
\hline \multicolumn{1}{|c|}{ Semantic Components } & $\begin{array}{c}\text { Hostile } \\
\text { (ground) }\end{array}$ & $\begin{array}{c}\text { Al'radi } \\
\text { al'Araqiya }\end{array}$ \\
\hline \hline $\begin{array}{l}\text { pertaining to or characterized of an enemy; } \\
\text { Pertaining to or engaged in actual hostilities }\end{array}$ & - & + \\
\hline $\begin{array}{l}\text { of the nature or disposition of an enemy; } \\
\text { unfriendly }\end{array}$ & - & + \\
\hline
\end{tabular}

Having presented the analysis of certain lexical items in (6) above, in terms of their semantic components and showing the extent of their emotiveness in the two languages and the possibility of their congruent rendition from English into Arabic, analyses and discussions of two translations of this text with respect to the CA and the suggestions of adequate translations are given below. The same thing will be done with the other sample texts in this study.

The procedure to be followed is entirely based on the analysis and comparison of two suggested translations of each of the sample texts. The focus of attention in the discussion will be the extent of congruity in the translation of certain lexical items between the SL and the TL within the framework of the aspect of emotiveness and the analysis of the items into their semantic components. The translations of other lexical items or sentences in these texts are beyond the scope of the present work.

Two professional certified translators translated the sample texts. They worked separately and were completely unaware of the subject matter and the aims of the study. To distinguish between these translations and to study them separately, the texts translated by each translator are referred to by different letters, viz., "A" and "B".

So, the analyses and discussion of the two translations representing text (6) are given below: 


\section{Translation (A)}

Laqad tama tanfeedh 'amaliyat tahreer al'Araq bimazeej min aldiqa wal sur'aa wal jur'a lem yatawaq'auha al 'adoo wa lem yashhaduha al 'alam min qabl. leqad arsalna alta'iraat walsawareekh min qawa'id wa sufun ba'aeeda wa lati istata'at an tudamir markazan lil'adoo 'aw tadrib mustawda'aan wahidan biltahdeed. Ina junood wa mushaat albahriya tama tawjeehuhum ila Baghdad 'abr 350 meel min 'rọ al'adoo fee wahida min 'sr'a 'amaliyat altaqadum lilasliha althaqeela fee altareekh, laqad açhartum lil'alam maharat wa quwat alquwat almusalaha alAmrikiya.

\section{Translation (B)}

Tamat 'amaliyat "tahreer al'Araq" bimazeej min aldiqa walsur'aa wa alhikma alati lem yatawaq'auha al'adoo wa alati lem yara al'alam mithluha min qabl. Falaqad qumna bi irsaal ta'iraat wa sawareekh ba'aeedat almada qadira 'ala tadmeer kata'ib al'adoo 'aw darb mawq'a wahid faqat min qawa'id ba'aeeda 'aw min bawakhir fee albahar. Tama takleef junood wa mushat bahriya ila Baghdad 'abr 350 meelan min al'radi alati yatahakam feeha al'adoo wa dhalika fee wahida min 'sr'a taqadum lilasliha althakeela fee altareekh. Laqad abdaytum lil'alam mahara wa qudrat alquwat almusalaha alAmrikiya.

It is noticeable that the lexical items: huriyat, 'adoo and ' $r d$ mu'adiya are inadequate translations of the English words 'freedom', 'enemy' and 'hostile ground' respectively. This is based on the CA and the emotive incongruity of these terms discussed in (4.4.1.2 above). They should be substituted by ghazoo 'invasion' or ihtilal 'occupation', al jaysh wa al sh'ab al 'Araqi ' Iraqi Army and people' and al 'radi al 'Araqiya 'Iraqi ground' respectively. However, the two translators in translations (A) and (B) of Text (1) did not 
112 Lexical Incongruity in Translations of American Political Speeches into Arabic

take the emotive values of these lexical items into consideration. Both focused on the literal translations of the words that have negative connotations in this context [-emotive] and translated them into: tahreer (the verb of the noun huriya), 'adoo and 'rd al 'adoo (appeared in Translation A) and al'radi alati yatahakam feeha al'adoo 'the ground controlled by the enemy' (appeared in Translation B). These renditions are emotively offensive to the Iraqi and Arab readers of the text.

The second example is culled from a political speech entitled "Defending the War" that President G.W. Bush delivered during his presidential campaign in York, PA (July 9, 2004), as seen below:

(7)

We confronted the dangers of state-sponsored terror, and the spread of weapons of mass destruction. We acted against two of the most violent and dangerous regimes on Earth. We have liberated over 50 million people. (Applause) America is safer because of our actions. The world is better off; America is once again proud to lead the armies of liberation.

Some lexical items in (7) convey different connotations for the Americans and Iraqis. As the 'weapons of mass destruction' aslihat al damaar alshamil have been proved a big lie that President G.W. Bush's Administration made use of to justify the unfair war on Iraq, this expression is highly emotive with a negative connotation [emotive] for the Iraqis and Arabs. Similarly, other words in this context have negative connotations [-emotive] for the Iraqis, Muslims and Arabs for being accused so, like: 'state-sponsored terror' dual tar'a al irhaab and 'most dangerous and violent regimes' akthar al 'n çima 'anfan wa khuturatan; while other words like: 'our actions' 'amaliyatuna (referring to the American's military attacks) and 'the armies of liberation' jyoosh al tahreer 
have positive connotations [+emotive] for the Americans and their allies only as they justify their war on Iraq.

Further, the lexical item 'liberate' yuharir that also occurs in the expression 'armies of liberation' is highly emotive [- emotiveness] packed with a negative effect on Iraqis and Arabs and its translation seems incongruent in this context. For a translator, it should be rendered as ghazoo or ihtilal as these are the real implicit meanings of the word that reflect the military intervention of America in the area and its real colonist tendency in these countries. The American policy in the area represented by its military operations was just to protect its interests by achieving full control over Iraq. Therefore, the word 'liberate' should not be translated with its literal meaning tahreer here. Rather, it should be substituted by ' invade' yaghazoo or 'occupy' yahtal that are associated with 'war, 'armed forces', 'aggression', 'death', 'violence', 'air raids', 'missiles', etc. These connotations show the bad effects of the unfair war and suffering of the Iraqis. However, 'liberate' here has positive connotations for President Bush's Administration and its allies. It has the semantic components as in Table 4:

Table 4. Componential Analysis of the Connotations of the of 'Liberate' and 'Yuharir'

\begin{tabular}{|c|c|c|}
\hline Semantic Components & Liberate & Yuharir \\
\hline \hline To free & + & - \\
\hline To set free & $?+$ & $?-$ \\
\hline To set at liberty & + & - \\
\hline To release from & $?$ & $?$ \\
\hline To set free from combination & $?$ & $?$ \\
\hline
\end{tabular}

By using the strategy of literal translation with addition (consists in providing any supplementary information or notes to make the TT 
114 Lexical Incongruity in Translations of American Political Speeches into Arabic

intelligible), the translator could manage the text emotively to his audience. Additions are provided within the text, usually between brackets, to indicate that they do not belong to the original ST, or as footnotes (Newmark 1988: 92). So, in the above text the translator should put the word 'invaded' and 'armies of invasion and occupation' between brackets next to 'liberated' and 'armies of liberation' to uncover the implicit meaning of these terms, i.e., the 'armies of liberation' are, in fact, not so and they have brought nothing but pain and tragedies to the areas they invaded.

\section{Translation (A)}

Laqad wajahna 'khtar alirhab alati tar'aha alduwal wa intishar aslihat aldamar alshamil, wa laqad qumna biltasaruf hiyal ithnayn min 'khtar 'andimat alhukum 'ala wajh al'rd, wa qumna bitahleel mayazeed 'an khamsoon milyoon min albashar (Tahleel wa Tasfeek), wa laqad asbahat Amerika akthar 'mnan bisabab ma qumna bihi wa asbaha al'aalam af dal mima kana 'alayhi wa America mara 'ukhra fakhura bi'an taqood juyoosh altahreer.

\section{Translation (B)}

Laqad wajahna makhatir alirhab almad'aoom min qibal hukumaat wa intishar aslihat aldamar alshamil wa itakhadhna 'jra'aat did ithnayn min akthar al'andima sharasatan wa khuturatan 'ala wajh al'rd. Kama qumna bitahreer akthar min 50 milyoon nasama (Tasfeek). wa lidhalika faAmerika 'l'aan akthar 'mnan nateejat alijra'aat alati qumna bitikhadhiha. Al'aalam ahsan halan; wa taftakhir Amerika maratan 'ukhra biqiyadatuha lijiyoosh altahreer.

The translations (A) and (B) above, both translators used the literal translations of the lexical items 'liberate' yuharir and' armies of liberation' jiyoosh altahreer that are highly emotive [- 
emotiveness] packed with negative connotations for Iraqis, Muslims and Arabs.In addition, their translation seems incongruent in this context (See the CA in example 7 above). These items will emotively sound better if the translator substitutes them by 'invade' yaghazoo or 'occupy' yahtal and 'armies of occupation' jiyoosh al ihtilal respectively. These connotations though have negative reflections on the readers in the TL (i.e., Arabic) as they are associated with the unfair war and suffering of the Iraqis, their effect will be less offensive than rendering them into their literal meanings merely. Other translation strategies that could be used to manage the text emotively for the audience in the TL are a literal translation with an addition between brackets or a footnote.

The third example is taken from a political speech entitled "the Struggle for Democracy in Iraq" that President G.W. Bush delivered to the World Affairs Council of Philadelphia, in Pennsylvania, December 12, 2005, as shown in (8):

Last month, my administration released a document called the "National Strategy for Victory in Iraq" -- and in recent weeks I've been discussing our strategy with the American people. At the U.S. Naval Academy, I spoke about our efforts to defeat the terrorists and train Iraqi security forces so they can provide safety for their own citizens. Last week before the Council on Foreign Relations, I explained how we are working with Iraqi forces and Iraqi leaders to help Iraqis improve security and restore order, to rebuild cities taken from the enemy, and to help the national government revitalize Iraq's infrastructure and economy. Today I'm going to speak in depth about another vital element of our strategy: our efforts to help the Iraqi people build a lasting democracy in the heart of the Middle East. I can think of no 
116 Lexical Incongruity in Translations of American Political Speeches into Arabic

better place to discuss the rise of a free Iraq than in the heart of Philadelphia, the city where America's democracy was born.

In (8) all the lexical items like: 'administration' 'dara, 'national strategy' alstrategiya alwataniya, 'victory' nasir, 'U.S. Naval Academy' alakademiya albahriya al Amerikiya, 'defeat' yuhzim, 'Council of Foreign Relations' majlis al'alakat alkharijiya, 'our strategy' strateejiyatuna have negative connotations [- emotive] for the Iraqis, while they have high positive emotive connotations [+emotive] for the American Administration. In addition, there are other lexical items with negative connotations [- emotive] for the Iraqis as they are associated with the unfair Iraqi government that serves its own interests and stands by Bush government at the expense of the safety and security of the Iraqi people. These are words and expressions like: 'Iraqi security forces' quwaat al'mn al'Araqiya, 'safety' al'mn, 'Iraqi forces' alquwat al'Araqiya, 'Iraqi leaders' alqada al'Araqiyoon, 'security' alwaḍ'a al'mni, 'order' niḍm, 'national government' hukuma wataniya and 'free Iraq' al'Araq alhur.

The text also includes some lexical items whose TL equivalents are incongruent to the SL words as they have different emotive values for the Iraqis and the Americans. For example, the words 'terrorists' irhabiyoon and 'enemy' 'adoo both refer to the 'legitimate Iraqi resistance' almuqawama al'Araqiya almashroo'aa or 'armed resistance' almuqawama al musalaha that represents the right of the honest Iraqis to fight against the occupied forces and their supporters for their liberty, security and independent country . They could not be referred to as 'terrorists' in this context, but as 'resistance' which has a negative connotation to the Americans. Thus, the translator should either substitute or use a literal translation with additions to render these items adequately with respect to their positive connotations [+emotive] to the TL readers. Tables 5 and 6 present the semantic components of 'resistance' almuqawama: Table 5. Componential Analysis of the Connotations of 'Terrorists' 
and 'Irhabyoon'

\begin{tabular}{|l|c|c|}
\hline \multicolumn{1}{|c|}{ Semantic Components } & Terrorists & Irhabyoon \\
\hline \hline $\begin{array}{l}\text { The Jacobins and their agents and partisans in } \\
\text { the French Revolution, especially to those } \\
\text { connected to the with the revolutionary } \\
\text { tribunals during the 'reign of terror' }\end{array}$ & $?$ & $?$ \\
\hline $\begin{array}{l}\text { Anyone who attempts to further his views by a } \\
\text { system of coercive intimidation }\end{array}$ & $?+$ & $?-$ \\
\hline $\begin{array}{l}\text { One who entertains professes, or tries to } \\
\text { awaken or spread a feeling of terror or alarm : } \\
\text { an alarmist, a scaremonger }\end{array}$ & + & - \\
\hline Characterized by or practicing terrorism & + & - \\
\hline
\end{tabular}

Table 6. Componential Analysis of the Connotations of 'Resistance' and 'Muqawama'

\begin{tabular}{|l|c|c|}
\hline \multicolumn{1}{|c|}{ Semantic Components } & Resistance & Muqawama \\
\hline $\begin{array}{l}\text { Dislike of or opposition to a plan, an idea, etc; } \\
\text { refusal to obey }\end{array}$ & - & + \\
\hline The act of using force to oppose & - & + \\
\hline The power not to be affected by something & - & + \\
\hline $\begin{array}{l}\text { A force that stops something moving or makes } \\
\text { it move more slowly }\end{array}$ & $?$ & $?$ \\
\hline The fact of not conducting heat or electricity & $?$ & $?$ \\
\hline $\begin{array}{l}\text { A secret organization that resists the } \\
\text { authorities, especially in a country that an } \\
\text { enemy has control of }\end{array}$ & - & + \\
\hline
\end{tabular}

The so-called 'democracy' aldimuqratiya that President Bush referred to in his speech has a negative emotive value for the Iraqis who have experienced nothing but lack of security, order, justice, human rights, stability and democracy under the American 
118 Lexical Incongruity in Translations of American Political Speeches into Arabic

occupation and the new Iraqi government. This is illustrated by the semantic components of this lexical in Table 7:

Table 7. Componential Analysis of the Connotations of 'Democracy' and 'Aldimuqratiya'

\begin{tabular}{|l|c|c|}
\hline \multicolumn{1}{|c|}{ Semantic Components } & Democracy & Aldimuqratiya \\
\hline \hline $\begin{array}{l}\text { Government by the people; that form of } \\
\text { government in which the sovereign power } \\
\text { resides in the people as a whole and is } \\
\text { exercised either directly by them or by } \\
\text { officers directed by them. }\end{array}$ & + & - \\
\hline $\begin{array}{l}\text { A social state in which all have equal rights } \\
\text { without hereditary or arbitrary differences } \\
\text { of rank or privilege }\end{array}$ & + & - \\
\hline $\begin{array}{l}\text { A state or community in which the } \\
\text { government is vested in the people as a } \\
\text { whole that class of the people which has no } \\
\text { hereditary or special rank or privilege, the } \\
\text { common people (in reference to their } \\
\text { political power). }\end{array}$ & + & \\
\hline $\begin{array}{l}\text { The members of the democratic party } \\
\text { collectively }\end{array}$ & + & \\
\hline
\end{tabular}

\section{Translation (A)}

Laqad asdarat idarati fee alshahar almadee watheeqa tusama (alsitratijiya alqawmiya lil nasir fee al'Araq) wa fee al'sabee'a al'kheera kuntu 'unakish stratijiyatuna ma'aa alsha'ab alAmriki, walaqad tahadathtu fee al'kadimiya albahriya alAmrikiya 'an juhudana fee hazeemat alirhabiyeen wa tadreeb quwat al'mn al'Araqi bihayth taqoom bitawfeer al'mn limuwatiniha, wa laqad sharaht 'mam majlis al'alaqat alkharijiya fee al'sboo'a almadi kayfa inana n'amal,a'aa alquwat al'Araqiya wa alqada al'araqiyeen 
'ala musa'adat al'Araqyeen 'ala tahseen al'mn wa 'sti'adat alnidam wa i'aadat bina' almudun alati ista'adnaha min al'adoo wa musa'adat alhukuma al'Araqiya alwataniya 'ala I'adat ihyaa' albunya altahtiya wa aliktisadiya lil'Araq wa 'ilyawm sawfa atahadath bi 'amuq 'an 'ansur hayawi aakhar fee stratijiyatunawa huwa juhooduna fee musa'adat alsh'ab al'Araqi 'ala bina' dimuqratiya da'ima fee qalb alSharq al'wsat wala astatee'a altafkeer fee makan ansab min qalb Filadilfiya (almakan aladhi wilidat feehi aldimuqratiya alAmrikiya) limunakashat bizoogh 'Araq jaded.

\section{Translation (B)}

'sdarat idarati fee alshahar almad̦i watheeqa bi'anwan "alsitratijiya alqawmiya lilintisaar fee al'Araq"- wa khilal al'sabee'a al'kheera qumtu bi munaqashat stratijiyatuna ma'aa alsh'ab alAmreeki. Kama tahadathtu fee al'kadimiya albahriya alAmrikiya 'an juhudana limukafahat alirhab wa tadreebuna liquwat al'mn al'Araqiya liyatamakanu min tawfeer al'mn limuwatineehum. Wa 'w d̦htu fee al'sboo'a almaḍi wa amam majlis al'alakat alkharijiya, alisloob aladhi natabi'ahu lil'amalma'aa alquwat al'Araqiya wa alqada al'Araqyeen limusa'adat al'Araq fee tahseen al'mn wa hufḍ alnidham wa i'adat bina' almudun alati tamat isti'adatuha min al'ada' wa musa'adat alhukuma alqawmiya fee ihya' albunya altahtiya wa iktisad al'Araq. Wa sawfa atahadath alyawm biltafseel 'an 'ansur aakharham jidan fee stratijiyatuna: almasa'ai alati naqoomu biha limusa'adat alsh'ab al'Araqi fee ta'sees niḍm dimukrati fee qalb alShark al'wsat. Wala yumkinuni altafkeer fee 'y makaan aakhar afḍl min qalb Filadilfiya limunaqashat nuhooḍ al'Araq kabalad hur haythu 'na hadhiyi almadeena hiya manbat aldimuqratiya alAmrikiya. 
120 Lexical Incongruity in Translations of American Political Speeches into Arabic

Although the above text is loaded with words and expressions that have high negative connotations for the Iraqis and Arabs, most of these words have positive connotations for the Americans as they are associated with heir "National Strategy of Victory in Iraq". Moreover, the two lexical items 'terrorists' irhabiyoon and 'enemy' 'adoo should not be translated literally in this context as their TL equivalents are incongruent to the SL words. Rather, they should be substituted by the words 'resistance' almuqawama for achieving a more emotively positive effect on the Iraqi and Arab readers. However, the two translators in (A) and (B) above ignored the emotive values of these lexical items and translated them literally only which is offensive to the Iraqis who have been fighting against the American occupation for the freedom of their country. The strategy of literal rendition with an addition or footnote is another alternative in this context.

The fourth text analysed is from a speech delivered by President G.W. Bush on "Post-Election Press Conference: The Resignation of Donald Rumsfeld" in Washington, DC, November 8, 2006, as seen below:

But we've got to make sure it isn't by implementing a strategy which helps -- a political strategy which helps unify the country and a security strategy which makes sure that the Iraqis are better capable of fighting off the extremists and the radicals that want to stop progress in Iraq.

The words and expressions: 'political strategy' stratejiya siyasiya, 'unify the country' tawheed albilad and 'security strategy' stratejiya 'mniya are associated with the political and security stability of Iraq which the country lacked under the umbrella of the American occupation and the daily sufferings it had brought for the Iraqis since the invasion. Thus, while these lexical items have positive 
connotations [+emotive] for President Bush and his administration, they are highly emotive for the Iraqis and packed with negative connotations [- emotiveness] as they had suffered from lack of political and security stability after the unjustified war on their country.

However, in this text, the lexical item 'extremists' and 'radicals' both translated into almutatarifoon have negative connotations [emotive] for President Bush and his administration as they consider them 'terrorists' and justify arresting and killing them, while they only represent the 'legitimate Iraqi resistance' or the 'armed resistance' almuqawama almusalaha that fights against the occupation forces for the freedom of its country and people. Therefore, the rendition of 'extremists and radicals' into mutatarifeen is incongruent in this context and the word 'resistance' almuqawama (see example 8 above) should be added between brackets to manage the emotive value of the item for the TL readers. The semantic components of 'extremists and radicals 'is given in Table 8 below:

Table 8. Componential Analysis of the Connotations of 'Extremists and Radicals' and 'Mutatarifeen'

\begin{tabular}{|l|c|c|}
\hline \multicolumn{1}{|c|}{ Semantic Components } & $\begin{array}{c}\text { Extremists } \\
\text { and } \\
\text { Radicals }\end{array}$ & Mutatarifeen \\
\hline \hline $\begin{array}{l}\text { Person whose opinions especially about } \\
\text { religion or politics are extreme and who } \\
\text { may do things that are violent, illegal, etc } \\
\text { for what they believe }\end{array}$ & - & + \\
\hline $\begin{array}{l}\text { Person whose ideas or actions are extreme } \\
\text { and not normal, reasonable or acceptable } \\
\text { to most people }\end{array}$ & $?$ & $?$ \\
\hline $\begin{array}{l}\text { Person with radical opinions, ideas and } \\
\text { principles (political and social) }\end{array}$ & - & + \\
\hline
\end{tabular}


122 Lexical Incongruity in Translations of American Political Speeches into Arabic

\section{Translation (A)}

Walakin 'alayna 'n nata'kad min 'nana bitikhadhina listrategiya tusa'ad - 'y strategiya siyasiya tusa'ad 'ala tawheed aldawla wa strategiya 'mniya taj'aluna nata'kad ' $n$ al'Araqyeen qadireen bishakil af d̦al 'ala muharabat almutatarifeen wa alradikaliyoon aladheena yuridoon ' $n$ yu'aiqu altaqadum fee al'Araq.

\section{Translation (B)}

Walakin 'alaynaalta'kud min 'n hadha laysa nateejat itib'a stratejiya tusa'ad 'ala ..... Stratejiya siyasiya tushim fee tawheed albalad wa siyasa 'mniya tadmin lilsh'ab al'Araqi qudra afdal fee muwajahat almutatarifeen wa althawriyoon aladhina yas'aoon liwaquf tatawir al'Araq.

As the two lexical items 'extremists' and 'radicals' almutatarifoon and alradikalyoon have negative connotations [- emotive] for President Bush and his administration who consider them 'terrorists', they represent the 'legitimate Iraqi resistance' or the 'armed resistance' almuqawama almusalaha that fights against the occupation forces for the freedom of its country and people. Therefore, the rendition of 'extremists and radicals' into mutatarifeen is incongruent in this context and the word 'resistance' almuqawama should be added between brackets to manage the emotive value of the item for the TL readers. The two translators in both (A) and (B) of this text failed in providing the right emotive equivalent of these terms in this context. In (A), the translator uses the two words almutatarifoon and alradikalyoon for 'extremists' and 'radicals'; while the translator in (B) used the words almutatarifoon and althawryoon 'revolutionists' for these terms . Both translations are incongruent in this context and they have high negative connotations [-emotive] to the Iraqi and Arab readers of the text. 
In the fifth and last example chosen from the speech President G.W. Bush delivered on the Four-Year Anniversary of the War in Iraq, Washington, DC, March 19, 2007; highly emotive overtones of lexical items are noticeable as presented in (10) below:

(10)

Four years after this war began, the fight is difficult, but it can be won. It will be won if we have the courage and resolve to see it through. I'm grateful to our servicemen and women for all they've done and for the honor they brought to their uniform and their country. I'm grateful to our military families for all the sacrifices they have made for our country. We also hold in our hearts the good men and women who've given their lives in this struggle.

In the context of (10), the lexical items 'war' harb, 'fight' m'araka, 'won' nasir, 'courage', shaja'aa, 'resolve' 'azim, and 'struggle' kifah are highly emotive with negative connotations [-emotive] to the Iraqis, as President Bush here was proud of winning the unfair war and occupying Iraq. The Iraqis felt how much pain, tragedies, suffering and destruction this war has brought to them. The Americas have invaded Iraq not by the courage and resolve of their Armed Forces, but by their use of internationally prohibited bombs and weapons. However, more positive connotations [+ emotiveness] these items have for the American Administration. Further, there are other words in this text that also have the same emotive values for the Americans, i.e., [+emotive] as they show President Bush praise of the American Armed Forces and the victory they have achieved in Iraq. On the other hand, these items have high negative connotations [- emotive] for the Iraqis as they are associated with the American military units and soldiers who occupied Iraq at the expense of the miseries and suffering of its women and children and the destruction of their homeland. These include items like: 
124 Lexical Incongruity in Translations of American Political Speeches into Arabic

'servicemen and women' aljunood wa almujanadaat, 'uniform' alzee al'askari, 'our country' (America) baladuna, 'military families' 'a'ilaat al 'askariyeen, 'sacrifices' taçhiyaat, ' the good men and women' (referring to the American Armed Forces) al'khyaar min alrijaal walnisa' and 'their lives' hayatahum.

Since the American's war on Iraq is viewed by many as unjustified and unfair, the translation of the word 'honour' into alsharaf in this context is incongruent as the semantic features of the two items illustrated in Table 9 below:

Table 9. Componential Analysis of the Connotations of 'Honour' and 'Sharaf'

\begin{tabular}{|l|c|c|}
\hline \multicolumn{1}{|c|}{ Semantic Components } & Honour & Sharaf \\
\hline \hline $\begin{array}{l}\text { High respect, esteem or reverence accorded to } \\
\text { exalted worth or rank; deferential admiration, appro- } \\
\text { bation as felt in the mind for some person or thing }\end{array}$ & + & - \\
\hline The expression of high estimation & + & - \\
\hline Glory, renown, fame, credit, reputation, good name & + & - \\
\hline $\begin{array}{l}\text { Personal title to high respect or esteem, nobleness of } \\
\text { mind, scorn of meanness }\end{array}$ & ?+ & ?- \\
\hline $\begin{array}{l}\text { A fine sense of and strict, allegiance to what is due } \\
\text { or right; to what is due according to some } \\
\text { conventional or fashionable standard of conduct. }\end{array}$ & + & - \\
\hline $\begin{array}{l}\text { A statement or promise made on one's honour } \\
\text { exalted rank or position; dignity, distinction }\end{array}$ & + & - \\
\hline $\begin{array}{l}\text { Something done or conferred as a token of respect or } \\
\text { distinction; a mark or manifestation of high regard; } \\
\text { a degree of nobility }\end{array}$ & + & - \\
\hline
\end{tabular}

In this case, a translator should use the strategy of addition after a literal rendition of this lexical item to maintain a more positive emotive value of the word in the TL. Accordingly, he should follow 
the literal translation of 'honour' as sharaf by the addition of the words 'shame' khizi and 'disgrace' 'aar between brackets.

\section{Translation (A)}

Wa ba'ad arba'a sanawat min bad' hadhihi alharb fa'na alqital layazal sa'aban lakin yumkin kasbahu, wa sawfa naksibahu idha kuna namtalik alshaja'aa wa altasmeem 'ala tahqeeqahu, inani mumtan lirijaluna wa nisa'una fee alkhidma (al'askariya) lima qamu bihi wa lilsharaf aladhi jalabuhu liziyahum wa libaladahum inani mumtan li'usar 'askariyeena liltaçhiyat alati qadamuha min 'jil watanuna wa 'inana 'yḍan nahfụ̣ fee qulubina alrijal wa alnisa' alsaliheen aladheena qadamu arwahahum fee hadha alnidal.

\section{Translation (B)}

Wa ba'ad arba'at a'awam mundhu bad' hadhihi alharb fala tazal alma'araka sa'aba walakin bimaqdurina alfawz. Wa yasbah alfawz mumkinan idha kan ladayna alshaja'aa wa altasmeem lil istimrar hata alnihaya. Wa ataqadam bil shukur liquwat aljaysh min alrijal wa alnisa' likul ma qamu bihi wa lilsharaf aladhi jalabooh limihnatihum wa baladihim. Wa ataqadam bil shukur li'usar al'amileen biljaysh lilta C̣hiyat alati qamu biha min ajl biladihim. Kama nahmil fee qulubina dhikra alrijal wa alnisa' al'brar aladhina faqadu hayatahum fee hadhihi alma'araka.

The above text is overloaded with words and expressions that have negative connotations for the Iraqis (See, 4.4.1.2) as they reflect the painful and tragic effects of the unfair war on Iraq and the American occupation of this country especially in this context President Bush praised the American troops and the victory they brought to America. Thus, the literal translation of the word 'honour' into shraf when President Bush was talking about the 
126 Lexical Incongruity in Translations of American Political Speeches into Arabic

honour his troops brought to their uniform and their country, seems incongruent in this context for these troops brought shame and disgrace to their country instead by the brutal and violent acts they did against the armless and innocent Iraqi women and children. Therefore, the words 'shame' and 'disgrace' khizi wa 'aar respectively could immediately follow as a gloss or a brief explanation between two brackets the literal translation of the word, as in:

Wa ataqadam bil shukur liquwat aljaysh min alrijal wa alnisa' likul ma qamu bihi wa lilsharaf [khizi wa 'aar] (Translator) aladhi jalabooh limihnatihum wa biladihim.

As it is the case in the translation of the previous texts of President G.W. Bush speeches, the two translators' renditions of this text, i.e., in (A) and (B) above; also translated the word 'honour' only literally without managing the texts emotively to seem more appropriate to the feelings of the TL Iraqi and Arab audience.

In a keynote speech in Egypt, President Barack Obama calls for a new beginning in US relations with the Muslim world and Arabs. However, it will be President Obama's actions that will reflect any serious change in achieving Middle East peace. Based on this new orientation in the American Administration's policy, the analysis and discussion of President Obama's political speeches will show more positive or neuter emotive values in comparison to these of President G.W. Bush and a more congruent rendition of the political terms. The first example is taken from President B. Obama's speech delivered in Cairo on June 4, 2009, as seen below:

That is why I ordered the removal of our combat brigades by next August. That is why we will honour our agreement with Iraq's democratically elected government to remove combat troops from Iraqi cities by July, and to remove all 
our troops from Iraq by 2012. We will help Iraq train its security forces and develop its economy. But we will support a secure and united Iraq as a partner, and never as a patron.

In (11), all the italic words have emotive overtone. As the Iraqi government has not changed since President Bush era and it is wellknown ever since of its bias stands and acts of violence towards certain national, religious and social groups and as the American troops are still occupying Iraq and their democratic project failed, some of the lexical items are packed with negative connotations [emotive]. They include words and expressions like: 'combat brigades' al'lwia almuqatila, 'democratically elected government' alhukuma almuntakhaba dimuqratiyan, 'combat troops' alquwat al muqatila, 'troops' alquwat, 'security forces' quwat alamn and 'patron' naseer or hami.

However, there are other lexical items in this context that have positive or neuter connotations [+emotive) or [ \pm emotive] as new changes are expected from the new policy of the American administration. Iraqis should be optimistic of the promises President Obama has made, but at the same time they have to wait and see his serious actions. These are words like: 'removal' raheel ,'honour' nahtarim, 'remove' sahib, 'help' yusa'aid, 'support' yad'am and 'partner' haleef. Therefore, the rendering of most of these words is congruent as their meanings have almost the same emotive values in the SL and the TL. The semantic components of the lexical items 'removal' and its literal Arabic equivalent raheel, for instance, are shown in Table 10 below:

Table 10. Componential Analysis of the Connotations of the 'Removal' and 'Raheel'

\begin{tabular}{|l|c|c|}
\hline \multicolumn{1}{|c|}{ Semantic Components } & Removal & Raheel \\
\hline \hline The act of taking away entirely & + & \pm \\
\hline
\end{tabular}


128 Lexical Incongruity in Translations of American Political Speeches into Arabic

\begin{tabular}{|l|c|c|}
\hline \multicolumn{1}{|c|}{ Semantic Components } & Removal & Raheel \\
\hline \hline The act of removing a person by murder & $?$ & $?$ \\
\hline $\begin{array}{l}\text { Dismissal from an office or post; transference } \\
\text { to another office }\end{array}$ & $?$ & $?$ \\
\hline $\begin{array}{l}\text { The act of conveying or shifting to another } \\
\text { place }\end{array}$ & + & \pm \\
\hline $\begin{array}{l}\text { The act of changing one's ground, place or } \\
\text { position; changing of habitation }\end{array}$ & $?+$ & $? \pm$ \\
\hline
\end{tabular}

Since the semantic components of both lexical items have almost identical emotive values, the translation of 'removal' into its Arabic equivalent raheel is congruent in this context. The same thing occurs with the other words that have positive / neuter connotations [+emotive] in both languages.

\section{Translation (A)}

Ina hadha huwa alsabab fee inane amartu bi sahb quwatuna almuqatila qabl ighsutus almuqbil wa hadha huwa alsabab aladhi yaj'aluna nahtarim itifaquna ma'aa alhukuma al'Araqiya almuntakhaba dimuqratiyan 'ala hisab alkata'ib almuqatila min almudun al'Araqiya qabl yulyu, wa sahib kul quwatuna min al'Araq qabl 'aam 2012 wa lasawfa nusa'ad al'Araq 'ala tadreeb quwatiha alAmrikiya al'mniya wa tatweer iktisaduha walakinana sanad'am qiyam 'Araq aamin wa muwahad kashareek wa laysa Abadan katabi'a.

\section{Translation (B)}

Lihadha alsabab asdartu al'mr bi sahib kafat alquwat almuqatila fee ighsutus almuqbil. Wa li hadha alsabab fasawfa naltazim bi itifaquna ma'a alhukuma al'Araqiya alati tama intikhabuha bitareeqa dimuqratiya wa sahib alquwat almuqatila min almudun al'Araqiya fee shahar 
yulyuwa sahib kafat alquwat min al'Araq fee 'aam 2012. Sawfa naqoom bi musa'adat al'Araq fee tadreeb quwat al'mn wa tanmiyat aliqtisad, Walakinana sawfa naqoom bi da'am 'Araq aamin wa muwahad kashareek wa laysa kamas'ool 'anhum.

This text contains words and expressions with high emotive overtone. In addition many other lexical items have positive or neutral connotations as the Iraqis and Arabs should be optimistic of the promises President Obama has made. Consequently, the translation of most of the rendering of most of these words is congruent as their meanings have almost the same emotive values in the SL and the TL.

The second example represents President Obama's speech on Iraq withdrawal, delivered on February 27, 2009. The text was posted by Scott Lucas (Enduring America, 2010) in Iraq, US Foreign Policy, as given below:

\section{(12)}

Next month will mark the sixth anniversary of the war in Iraq. By any measure, this has already been a long war. For the men and women of America's armed forces - and for your families - this war has been one of the most extraordinary chapters of service in the history of our nation. You have endured tour after tour after tour of duty. You have known the dangers of combat and the lonely distance of loved ones. You have fought against tyranny and disorder. You have bled for your best friends and for unknown Iraqis. And you have borne an enormous burden for your fellow citizens, while extending a precious opportunity to the people of Iraq. Under tough circumstances, the men and women of the United States military have served with honor, and succeeded beyond any expectation.

(B. Obama, February 27, 2009) 
130 Lexical Incongruity in Translations of American Political Speeches into Arabic

The text in (12) is charged with lexical items of high emotive overtone. Words and expressions like: 'six anniversary' aldhikra alsanawiya alsadisa, 'war' alharb, 'long war' harb taweela, 'men and women of America's armed forces' rijal wa nisa' alquwat almusalaha alAmrikiya, 'families' (of the American Armed Forces) 'awa'il, 'chapters of service' fusool alkhidma, 'nation' (America) 'uma, 'tour of duty' jawla fee alkhidma al'askariya, 'combat' alqital, 'fought' haraba, 'men and women of the United States military' rijal wa nisa' alquwat almusalaha alAmerkiya, 'served' khidma, 'honor' sharaf, 'succeeded 'najahu; have positive connotations [+emotive]for the Americans, while they have negative connotations [- emotive]for the Iraqis as they are associated with the American occupation of their country and the miseries it has brought to the Iraqis. The two words 'tyranny' alistibdad and' disorder' alfaw da are also packed with negative connotations [-emotive] for the Iraqis as 'tyranny' and 'disorder' are the result of the Americans invasion of their peaceful country.

Other lexical items have negative connotations [-emotive] to the Americans, but neutral [temotive] to the Iraqis. They include words and expressions like: 'lonely distance' alb'ad wa alwahda, 'loved ones' 'hibaa', 'bled' nazaf, 'best friends' af çal al'sdiqaa', 'fellow citizens' (American citizens) muwatineen and 'endure' yatahamal. They are highly charged with emotive overtones for the Americans, but they look odd to the Iraqis with neutral connotations or even negative ones.

Although these lexical items have different emotive values in both languages, their rendition is congruent. Only the translation of the word 'honour' into sharaf seems incongruent (see, example 10 above) as it is associated with 'shame' and 'disgrace' of the unfair war on Iraq. The same thing is applicable to the item 'succeeded' that the translator should add the word 'failed' next to it as the war was unequal and unjustified between America and Iraq and success could not be achieved at the expense of the suffering and destruction 
of a whole country. The semantic components of 'succeed' and its literal translation are illustrated in Table 11below:

Table 11. Componential Analysis of Connotations of 'Succeed' and 'Najaha'

\begin{tabular}{|l|c|c|}
\hline \multicolumn{1}{|c|}{ Semantic Components } & Succeed & Najaha \\
\hline \hline $\begin{array}{l}\text { To achieve something that you have been trying } \\
\text { to do or get }\end{array}$ & + & - \\
\hline $\begin{array}{l}\text { To be successful in your job , earning money, } \\
\text { power, respect, etc }\end{array}$ & $?$ & $?$ \\
\hline $\begin{array}{l}\text { To come next after sb / sth and take their / its } \\
\text { place or position }\end{array}$ & $?$ & $?$ \\
\hline To gain the right to a title, property, etc & $?+$ & $?-$ \\
\hline
\end{tabular}

\section{Translation (A)}

Sayashad alshahr alqadim aldhikra alsadisa lilharb 'ala al'Araq wa bikul almaqayees fa'na hadhihi alharb kanat harb taweela, wa laqad kanat hadhihi alharb bilnisba lakum lirijal wa nisa' alquwat almusalaha alAmrikiya wa li'aa'ilatukum min akthar alfusool ghayr al'adiya lilkhidma fee tareekh 'umatuna, laqad tahamaltum jawla ba'ad jawla ba'ad jawla min jawlat alwajib, laqad 'araftu makhatir almuwajaha wa masafat albu'ad 'an ahiba'kum, laqad harabtum dhid altughyan wa alinfilat, laqad nazaftum aldima' min 'jl a'az asdiqa'kum wa min 'jl 'Araqyeen ghayr ma'aroofeen, wa laqad tahamaltum a'aba' ha'ila min ' $j l$ muwatineekum wa 'ntum tamnahoon alsha'ab al'Araqi fursa thameena, laqad khadama rijal wa nisa' aljaysh alAmreeki bikul sharaf tahta duroof sa'aba wa najahu najahan faq kul altawaqu'at. 
132 Lexical Incongruity in Translations of American Political Speeches into Arabic

\section{Translation (B)}

Yumathil alshahr alqadim aldhikra alsanawiya aldadisa lilharb fee al'Araq. Wa bikul almaqayees faina hadhihi alharb tumathil atwal harb fee al'alam hata alaan. Wabilnisba lirijal wa nisa' alquwat almusalaha alAmrikiya wa bilnisba li'aa'ilatuhum fa ina hadhihi alharb tu'atabar safha ghayr 'adiya min tareekh alkhidma al'askariya fee watanuna. Falaqad tahamaltum dawra b'ada 'ukhra li'da' alwajib. Laqad wajahtum makhatir alharb wa bu'ad almasafa 'an al'hiba'. Laqad khu d̦tum harban did al çulum wa alfaw da. Laqad nazaftum daman min jil rifaqikum wa min 'jil 'Araqiyeen laysa lakum bihim 'y ma'arifa. Laqad tahamaltum 'ab' kabeer min 'jil muwatinee baladikum fee nafs alwaqt aladhi tamakantum feehi min 'n tuqadimu lisha'ab al'Araq ma yasnah lahu fursa thameena. Qam rijal wa nisa' jaysh alwilayat almutahida alAmrikiya bilkhidma that duroof qasiya wa 'hrazoo najahan yafooq altasawir.

The words and expressions in this text are of high emotive overtone. However, there rendition is congruent despite the different emotive values they have in both languages.No instances of incongruent renditions are noticeable in this text except that of the word 'honour' (See examples 10 and 12 above) which should be followed by the words 'shame 'and 'disgrace' between brackets after the literal rendition of the item. The first translator in (A) above rendered the word literally without considering its negative emotive effect on the TLIraqi and Arab audience. The translator in (B), on the other hand, did not translate the word .So, both renditions are considered inadequate in this context.

The third example is taken from the same speech of President Obama in text (12) above: 


\section{(13)}

In the coming months, my administration will provide more assistance and take steps to increase international support for countries already hosting refugees; we'll cooperate with others to resettle Iraqis facing great personal risk; and we will work with the Iraqi government over time to resettle refugees and displaced Iraqis within Iraq - because there are few more powerful indicators of lasting peace than displaced citizens returning home.

(B. Obama, February 27, 2009)

This text includes more positive connotations for the Iraqis who expect a better American policy based on mutual understanding and a complete withdrawal of the American troops from Iraq as President Obama has promised. Thus, lexical items like: 'administration' idara , 'assistance' musa'ada, 'international support' da'am duwali, 'resettle' 'i'adat tawteen, 'lasting peace' salam da'im and 'home' diyaar can be rendered congruently without any translation problem between the SL and the TL as they almost have identical emotive values. However, there still in the same contexts, words and expressions that are tied with the prevailed political situation and accordingly they have negative connotations [-emotive] as it is the case with: 'refugees' laj'oon, 'personal risk' makhatir shakhsiya, 'Iraqi government' al hukuma al 'Araqiya, 'displaced Iraqis'(within Iraq) almuhajroon al'Araqiyoon dakhil al'Araq, 'displaced citizens' al muwatinoon al muhajaroon. Since the emotive values are negative in the TL (Arabic) while neuter in the SL (English), the rendition of these political terms suffer from no translation problems between the two languages. For instance, the semantic components of 'displaced' and its Arabic equivalent muhajaroon (that is packed with a high negative connotation for the Iraqis) are almost identical as shown in Table 12 below: 
134 Lexical Incongruity in Translations of American Political Speeches into Arabic

Table 12. Componential Analysis of the Connotations of 'Displaced' and 'Muhajaroon'

\begin{tabular}{|l|c|c|}
\hline \multicolumn{1}{|c|}{ Semantic Components } & Displaced & Muhajaroon \\
\hline \hline $\begin{array}{l}\text { A person whose place has been taken } \\
\text { from him }\end{array}$ & \pm & - \\
\hline $\begin{array}{l}\text { A person who has been forced to move } \\
\text { away from his home to another place }\end{array}$ & \pm & - \\
\hline Something moved from its usual position & $?$ & $?$ \\
\hline Somebody moved from a job or position & $?$ & $?$ \\
\hline
\end{tabular}

\section{Translation (A)}

Sawfa taqoom idarati fee alshuhur alqadima litaqdeem alda'im wa itikhadh alkhutuwat fee sabeel ziyadat alda'am alduwali alati ta'wi laji'een wa sanata'awan ma'aa duwal 'ukhraa li' adat tawteen al'Araqiyeen aladhina yuwajihoon makhatir shakhsiya jaseema, wa san'amal ma'aa alhukuma al'Araqiya 'ala madar alwaqt li' 'adat tawteen almuhajireen wa almub'adeen al'Araqyeen dakhil al'Araq li'ana hunaka qaleel min aldala'il sayakoon alqawiya 'ala in alsilah alda'im sayakoon 'qwa 'anda 'awdat almuwatineen almub'aadeen ila alwatan.

\section{Translation (B)}

Sawfa taqoom idarati khilal alshuhur alqadima bitawfeer musa'adat idafiya wa sawfa tutakhadh ijra'at liziyadat alda'am lilduwal alati taqoom haliyan bi'iwa'allaji'een ; wa sawfa nata'awan ma'a alaakhareen li'"adat tawteen al'Araqyeen aladheena yuwajihun makhatir shakhsiya jama;wa sawfa na'amal ma'aa alhukuma al'Araqiya ma'aa alwaqt lii'aadat tawteen allaji'een wa al'Araqiyeen almusharadeen min diyarihim dakhil al'Araq - wa alsabab fee dhalika anahu tujad mu'shirat qawiya tusheer ila 
imkaniyat salam da'im akthar min imkaniyat 'awdat almuwatineen lidiyarihim.

Most of the words and expressions in this text have positive emotive values for the Iraqis as they expect a better American policy based on mutual understanding and a complete withdrawal of the American troops from Iraq as President Obama has promised. Therefore, the rendition of these political terms suffers from no translation problems between the SL and the TL.

Like the previous examples, the fourth text is taken from President Obama's speech on Iraq withdrawal, delivered on February 27, 2009, as presented in (14) below:

You are a great nation, rooted in the cradle of civilization. You are joined together by enduring accomplishments, and a history that connects you as surely as the two rivers carved into your land. In years past, you have persevered through tyranny and terror; through personal insecurity and sectarian violence. And instead of giving in to the forces of disunion, you stepped back from a descent into civil war, and showed a proud resilience that deserves respect.

In this part of his speech, President Obama showed high appreciation and respect to the Iraqi old civilization, history and accomplishments. He also praised the determination of the Iraqis in the present time and how they stepped back from a descent into civil war. Therefore, words and expressions like: 'great nation' 'uma 'adima, 'cradle of civilization' mahd alhadara, 'two rivers' alnahrayn, 'land' al'rd and 'proud resilience' muroona tad'au lil fakhar; are packed with positive connotations [+emotive]. Yet, there are other lexical items in this context that have negative connotations [-emotive] for their association with the pain and 
136 Lexical Incongruity in Translations of American Political Speeches into Arabic

suffering that result from this war and the acts of violence that follow. These are words and expressions like: 'tyranny' alistibdad, 'terror' alirhaab, 'insecurity' in'adam al ' $m n$, 'sectarian violence' al'anf alta'ifi , 'forces of disunion' qiwa al'nfisal and 'civil war' alharb al'hliya.

Thus, almost all the lexical items in this context have identical emotive values in both languages. This makes the rendition of a SL word congruent with its TL equivalent. Table (13) shows the semantic components of 'terror' and its Arabic equivalent Irhaab as an example illustrating this point:

Table 13. Componential Analysis of the Connotations of 'Terror' and 'Irhaab'

\begin{tabular}{|c|c|c|}
\hline Semantic Components & Terror & Irhaab \\
\hline \hline A feeling of extreme fear & $?$ & $?$ \\
\hline $\begin{array}{c}\text { A person, situation or thing that makes you } \\
\text { very afraid }\end{array}$ & $?-$ & $?-$ \\
\hline $\begin{array}{c}\text { Violent action or the threat of violent action } \\
\text { that is intended to cause fear, usually for } \\
\text { political purposes }\end{array}$ & - & - \\
\hline $\begin{array}{c}\text { A person ( usually a child) or an animal that } \\
\text { causes you trouble or is difficult to control }\end{array}$ & $?$ & $?$ \\
\hline
\end{tabular}

\section{Translation (A)}

Inakum 'uma 'adhima naba'at judhurukum min mahd alhadarat, laqad itahatum ma'an bi injazat rasikha wa tareekh yarbitukum ma'an bi kul ta'keed lalnahrayn almahd̦rayn fee ard̦ikum, laqad samatum fee alsanawat alsabuqa fee muwajahat altughyan wa alirhab dhid fuqdan al'mn alshakhsi wa al'aunf alta'ifi, wa badalan min alistislam liqiwa alinfisal falaqad taraja'atum ila alwara' min alqabaliya wa alharb al 'hliya wa a thartum muroona 
yufkhar biha wa tastahiq alihtiram.

\section{Translation (B)}

Antum 'uma adheema wa tamtad judhoorukum limahd alhadarat. Kama yajma'aukum sawiyan injazat Tabriz quwa tahmilukum wa tareekh rasikh yarbut baynakum karusookh alnahrayn aladhayn yashuqan ardukum . Laqad samatum fee almadi did aldulm wa alirhaab aladhi tamathala fee 'adam tawafur al'mn alshakhsi wa al'aunf alta'fi. Wa badalan min an tastaslimu li'awamil altafriqa falaqad taraja'atum 'an altaradi liharb 'hliya wa 'bdaytum muqawama yuftakhar biha wa tastahiq al 'shada.

There are no translation incongruncies here as almost all the lexical items in this context have identical emotive values in both languages. This makes the rendition of a SL word congruent with its TL equivalent. The two translators in (A) and (B) translated the text literally as it is supposed to be with an adequate choice of the TL equivalents.

The fifth sample is culled from President Obama's speech on Iraq withdrawal he delivered on February 27, 2009 and is shown in (15) below:

So to the Iraqi people, let me be clear about America's intentions. The United States pursues no claim on your territory or your resources. We respect your sovereignty and the tremendous sacrifices you have made for your country. We seek a full transition to Iraqi responsibility for the security of your country. And going forward, we can build a lasting relationship founded upon mutual interests and mutual respect as Iraq takes its rightful place in the community of nations. 
138 Lexical Incongruity in Translations of American Political Speeches into Arabic

In (15) President Obama shows more positive intentions towards the Iraqis and their country. He also talks about better future relationship between America and Iraq. In general, most of the lexical items in this text are packed with positive connotations [+emotive] for the Iraqis as they are associated with their country and its sovereignty. These are words like: 'territory' ' $r d$, 'resources mawarid, 'sovereignty' siyada, 'tremendous sacrifices' taçhiyat ha'ila, 'country' balad, 'full transition 'intikaal kamil and 'security' 'mn.

Although the Iraqis are more optimistic with President Obama's words, they need time to see to what extent what he said will be achieved by serious positive actions. So, what is packed with positive connotations [+emotive] for the American administration, may have neuter emotive value [ \pm emotive] for the Iraqis despite the possibility of congruent rendition of the lexical items between the SL and the TL. These are expressions like: 'lasting relationship' 'alaka da'miya, 'mutual interests' masalih mutabadala, 'mutual respect' ihtiram mutabadal and 'rightful place' makanahu alsaheeh.

\section{Translation (A)}

Lidhalik fa'la alsh'ab al'Araqi da'auni 'uwaḍh lakum nawaya Amerika, ina alWilayat AlMutahida la tas'aa ila 'y atma'a fee ardikum aw mawaridikum, inana nahtarim siyadatikum alwataniya wa taḍhiyatikum alha'ila alati qadamtumuha min 'jl dawlatikum wa fee sa'ayuna ma'an lilamam nastatee'a an nabni 'alaqat da'ima mabniya 'ala almasalih almushtaraka wa alihtiram almutabadal baynama yahtal al'Araq makanihi alla'ik fee masaf al'umam.

\section{Translation (B)}

Walil sh'ab al'Araqi, fainani awid an 'uqadim tawdeehan fa lays lil Wilayat AlMutahida AlAmrikiya 'y maza'im 'ala aradeekum aw mawaridikum. Fanahnu nahtarim siyadat 
biladikum wa alta d̦iyat al'ad̦eema alati qumtum biha min 'jil baladikum. Wa nas'aa litahweel tam litakoon mas'uliyat 'mn biladikum mas'uliya 'Araqiya. Wa sawfa yakoon altawajuh nahwa t'sees 'alaqa 'sasuha almasalih wa al'htiram almutabadal 'andama yahtal al'Araq mawqi'ahu alsaheeh fee almujtama'a alduwali.

Here, although the Iraqis are more optimistic with President Obama's words, they need time to see to what extent what he said will be achieved by serious positive actions. So, what is packed with positive connotations [+emotive] for the American administration, may have neuter emotive value [ + emotive] for the Iraqis despite the possibility of congruent rendition of the lexical items between the SL and the TL. In general, no translation problems faced the translators in (A) and (B) and they translated the text literally with congruent equivalents between the two languages.

Finally, it is worth mentioning that the best strategies that can solve translation problems associated with differences in the emotive values of lexical items between the SL and the TL are substitution of lexical items with positive connotations, to follow the literal translation of the SL word by a gloss and a brief explanation or even a footnote in the immediate context. However, although these may solve the problem, they will weaken the text. Further, the translators' additions and substitutions provided within the text should be put between brackets followed by (-Al-Mutarjim)or (- The translator) to indicate that these do not represent the additions of the ST writer, i.e., they are suggested by a translator to avoid offending the feelings, ideas, conventions or values of the TT reader.

\section{Conclusion}

In the present paper, an attempt has been made to investigate the 
140 Lexical Incongruity in Translations of American Political Speeches into Arabic

problems and implications of translating lexical items of American political speeches in terms of their connotations and aspects of emotiveness.It can be seen that culture, language and politics are inseparable and they go parallel in the sense that one cannot exists apart from the others. So, a deep understanding of the political culture of the SL is essential if the political terms are to be appropriately translated into the TL. One of the major difficulties in the translation of English political terms into Arabic and vice versa is attributed to the fact that Arabic political lexical items and terminology is charged with high emotive meanings. There is often more sensational power behind such items than the meaning they intend to carry. A translator should know how to reconstruct the meaning of the SL and how to convey it to the readers of the TL without negatively or offensively affecting them. The translator, in such cases is considered as biased, because he chooses lexical items that solely serve her own purposes, while pretending to be objective. In other words, translators use certain words for their emotive overtones rather than for honesty and equivalence. They may completely be faithful to the ST, but the reader needs further explanation. Therefore, a translator should not be neutral and should become involved by managing the text rather than only monitoring it. Managing a text emotively could happen in argumentative text types of which political speeches are common genres. Further, a translator should be trained to be able to render fully and efficiently the relevant features of managing. However, any changes from the ST should not be regarded by the critic as violating the principle of fidelity. Regarding the translation of lexical elements, the standard must be "adequacy." A kind of mirror-image literal accuracy so often demanded in the TL cannot serve as an objective criterion because the vocabularies of any two languages (with their structural and conceptual differences) simply cannot coincide completely.

The study has also revealed that CA is of a greater use to the translator. It can be used to distinguish the meanings of SL lexical 
items when their TL equivalents have widely different functional and/or descriptive components. It has been observed that the translation of political lexical items from English into Arabic shows certain problems due to differences between the SL and the TL. These involve the aspect of emotiveness and connotations, cultural expressions and lexical non-equivalence in a given context (i.e., a translator may render a word differently from one language into another according to the context of the text).

In this study, the analysis of the translations has shown that certain lexical items have different emotive meanings, i.e., either positive or negative which vary from one language to the other constituting a problem in translation. Types of emotive expressions found in the data can be categorized into [+ emotiveness], [emotiveness] or [temotive].One criterion which marks the level of congruent meanings in translation is to preserve the connotations of the original. Non-equivalent translation of the political words and expressions found in the data of the present study is due to the different emotive values of their connotative meanings between English and Arabic. Sometimes it is difficult to find an appropriate equivalent and sometimes it is even impossible to find one at all. The data shows instances where it is difficult to adequately convey the emotive meaning of numerous connotative lexical items as in: 'terrorists' irhabiyoon, 'liberate' yuharir, etc., which can be illustrated clearly in terms of CA procedure in translation. It is this procedure that shows the extent to which the rendering of a political lexical item is congruent or incongruent.

Mistranslations of highly emotive items for the TL audience occur in the data. This is due to the fact that both translators in this study have overlooked the emotive effects and connotative meanings of these items when translating the sample texts taken from the political speeches of Presidents G.W. Bush and B.Obama. They translated the words and expressions that have emotive overtone literally taking into consideration their denotative meaning 
142 Lexical Incongruity in Translations of American Political Speeches into Arabic

in the TL merely. No signs of translating the connotative meaning of the political terms are found in the texts rendered by each of the translators.For example, the analysis of the two translations, i.e., (A) and (B) manifest instances of mistranslation, like 'enemy ' into 'adoo and 'hostile ground' into ' $r d m u$ 'adiya etc. This is mainly due to overlooking connotative meanings and emotive effects which vary from one language to another. Consequently, translators should not ignore this factor which is a prerequisite for an adequate and appropriate translation.

It is also found that more lexical incongruity occurs in the translation of the political speeches of President G.W.Bush than in these of President B.Obama. This is due to the high negative overtones [- emotive] of their words and expressions that have almost no equivalents when translated into Arabic. It is said that many Arabs have been unhappy with Bush's policy towards the Muslims and Arabs in general. President Obama, on the other hand wants to improve the American image in the Islamic and Arabic world especially in the Middle East that his predecessor Bush have shown. Thus, no or very little lexical incongruities appear in the translation of the sample texts taken from his speeches. This is based on the fact that all translators' choices, from what to translate to how to translate, are determined by political agendas. Translators, therefore, are highly influenced by the political context and this determines whether their translation of a political text will emotively be negative or positive and whether the translation of a lexical item is congruent or non-congruent in the TL. On the other hand, most of the political lexical items occurring in the sample texts representing President B.Obama's speeches have the features of either positive [+emotive] or neuter [ found in translating these terms into the TL. This is due to the hope that most of the Arabs have in the new American Administration and its new policy towards Arabs and the Muslim's World. Many praised President Obama's speech in Cairo as a positive shift in U.S. 
attitude and tone. President Obama aims to repair ties with the Muslim world that have been strained under his predecessor President G.W.Bush.

Finally, due to certain lexical incongruence in English-Arabic translation in this study, which results in untranslatable items, some translation strategies, namely, substitution and literal translation annexed with a brief explanation are suggested to make the translation of these items possible as they are politically cultural bound.

To reiterate, a complete congruence in translating some emotive expressions from one language to another seems a far-fetched task. Yet, a translator has to try hard by considering the emotive aspect in his translation, for he can intervene in the original text of a political speech to manage its impact, being culturally and linguistically highly competent in the two languages (SL and TL) and making use of CA as a useful procedure in the translation of connotations along with other translation strategies (i.e., substitution, translation paraphrase, literal translation with a footnote, gloss, etc.) in order to preserve the connotative meaning in his/her translation. In fact, translators must be keenly sensitive to these strategies in order to appreciate how many of the available lexical and grammatical choices have political overtones. Normally, the translator carries out CA only on a word of some significance in the TL text which cannot adequately be translated one-to-one.

\section{References}

Abdul-Rahman, S. 1997. Linguistic and Extralinguistic Aspects of Arabic-English Political and Diplomatic Consecutive Interpretation. Unpublished Ph.D. Dissertation. Baghdad: Al-Mustansiriyya University.

Al Baik, D. 2009. Some Arabs Inspired, Others Unimpressed after 
144 Lexical Incongruity in Translations of American Political Speeches into Arabic

Obama's Speech. GULFNEWS. June 4, 2009. Available at URL $<$ http://gulfnews.com/>

Al-.Najjar, M. 1984. Translation as a Correlative of Meaning: Cultural and Linguistic transfer between Arabic and English. Bloomington: Indiana University.

Hussein, S. 2010. Address by President Saddam Hussein on the Anniversary of Power Aggression. Jan 17, 1999. Available at URL < http://www.almansore.com/Merath/MK-Mo21.html > .

Alvarez, R. \& V. C-A.M. (eds) (1996) Translation, Power, Subversion. Clevedon: Multilingual Matters.

Arab World Sees Positive Shift in Obama Speech. 2009. MSNBC News Services. June 4, 2009. Available at URL

$<$ http://www.msnbc.msn.com/id/31105705/ns/world_newsmideastn_africa//>

Aziz, Y. 1990. Mabadi' ul-Tarjama min al ingiliziyya ila al'Arabiyya. Mosul: University of Mosul.

Bassnett, S. 1980/1991. Translation Studies. London and New York: Routledge, 2nd edn.

Beard, A. 2000 .The Language of Politics. London: Routledge.

Beaugrande, D. \& Dressler, W. 1981. Introduction to Text Linguistics. London: Longman.

Beaugrande, D. 1984. Text Production: Towards a Science of Composition. Norwood, NJ: Ablex.

Brook, C. \& W. Penn. 1970. Modern Rhetoric. 3rd ed. New York: Harcourt, Brace and World Inc.

Bush, G. Speech on End of Major Combat in Iraq. 2003 May 1. San Diego CA Available at URL $<$ http://www.presidentialrhetoric.com/speeches/05.01.03.html> . Speech Defending the War in Iraq. 2004 July 12. Oak Ridge TN. Avalable at URL

$<\mathrm{http}$ //www.presidentialrhetoric.com/speeches/07.12.04.html> . Speech on the Struggle for Democracy in Iraq. 2005 May 12. Philadelphia PA. Available at URL 
$<$ http://www.presidentialrhetoric.com/speeches/12.12.05.html $>$ . Post-Election Press Conference: The Resignation of Donald Rumsfeld. 2006 Nov 8. Washinton D.C. Available at URL $<$ http://www.presidentialrhetoric.com/speeches/11.08.06.html> . Address on the Four-Year Anniversary of the War in Iraq. 2007 Mar 17. Washington D.C. Available at URL

$<\mathrm{http}: / / \mathrm{www}$.presidentialrhetoric.com/speeches/03.19.07.html > Catford, C. 1965. A Linguistic Theory of Translation. Oxford: Oxford University Press.

Charteris-Black, J. 2005. Politicians and Rhetoric: The Persuasive Power of Metaphor. New York: Palgrave Macmillan.

Crystal, D. \& D. Derek. 1969. Investigating English Style. London: Longman Group Ltd.

Crystal, D. 1985. A Dictionary of Linguistics and Phonetics. Oxford: Basil Blackwell Ltd.

Duff, A. 1981. The Third Language - Recurrent Problems of Translation into English. Oxford: Pergammon Institute of English.

El Solh, R. 2009 . Obama and Partnerships with Arabs. Arab Affairs Journal, 193. Available at URL

$<\quad$ http://www.arabaffairs.org/PDFFiles/raghed\%20alsolehe.pdf $>$

Fairlough, N. 1995. Media Discourse. London: Edward Arnold.

Farghal, M. 1994. Ideational Equivalence in Translation in Beaugrande, R. de. et al., (eds), Language, Disocourse and Translation in the West and Middle East. Vol.7. Amsterdam: John Benjamins Publishing Company. 55-63.

Haskett, G. 2010. The Language of Political Speech and Power. Available at URL $<$ http://www.blogher.com/language-politicalspeech-and-power $>$

Hatim, B. \& Mason, I. 1990. Discourse and the Translator. London: Longman Group Ltd.

Kal, C. 2009. Comment on Obama, Arab \& Muslim Opinion and 
146 Lexical Incongruity in Translations of American Political Speeches into Arabic

Narratives Available at URL

$<$ http://themoornextdoor.wordpress.com/2009/12/05/obamaarab-muslim-opinion-and- narratives-thoughts- comments/ $>$

Kasimi, M. 1982. The Distinctive Features of the Arab Culture. AlLisan Al-'Arabi 19.1, 8-14.

Kuhiwczak, P. \& L. Karin. (eds.) 2007. A Companion to Translation Studies. Clevedon: Multilingual Matters Ltd.

Lakoff, R. 1972. Hedges: A Study in Meaning Criteria and the Logic of Fuzzy Concepts, in Hockney, D,. et al. (eds.). Contemporary Linguistic Semantics. Dorecht: D. Reidel.

Lasswell, D. \& L. Nathan. 1965. Language of Politics. Cambridge: M. I. T. Press.

Leech, G. 1981. Semantics: The Study of Meaning. 2nd ed. Harmondsworth, Middlesex, England: Penguin Books Ltd.

Lena, K. 2009. Linguistic features in political speeches: how language can be used to impose certain moral or ethical values on people. Lulea (Swedish): Lulea University of Technology.

Lushin, A. 1995. Semantics: Theory and Practice. Benghazi: Qaar Younis University.

Lynch, M. 2009. The Conversation. The National. February 20. Available at URL

$<$ http://www.thenational.ae/article/20090220/REVIEW/771649 $250 / 1008>$

Weiss Y. 2008 Dec 8. Emergency Protest to stop the Massacre in Gaza. New York NY Available at URL

$<$ http://www.nkusa.org/activities/Speeches/20081227.cfm>

Newmark, P. 1981. Approaches to Translation. Oxford: Pergammon Press.

. 1988. A Textbook of Translation. Hertfordshire: Prentice Hall. . 1999. Paragraphs on Translation, The Linguist 38.1, 30-32.

Nida, A. 1965. Toward A Science of Translating. Leiden: E.J. Brill. . 1969. "Linguistics and Ethnology in Translation-Problems," in Hymes, Dell (ed.) Language in Culture and Society. New York: 
Harper and Row.

. 1979. Componential Analysis of Meaning .Cambridge: Mouton Publishers.

. 1982. Translating Meaning. San Dimas, California: English Language Institute.

Nida, E. \& T. Charles. 1969. The Theory and Practice of Translation. Leiden: E. J. Brill.

Obama, Barack. Speech on Iraq Withdrawal. Camp Lejeune NC. 2009 Feb 27. Available at URL

$<$ http://enduringamerica.com/2009/02/27/text-obama-speechon-iraq-withdrawa $>$

. Speech in Cairo. Cairo Egypt. 2009 Feb 4. Available at URL $<$ http://www.nytimes.com/2009/06/04/us/politics/04obama.text .html?pagewanted $=$ all $>$

Omar, M. 1982. Semantics. Kuwait: Daar Al-Urūba Publication.

Palmer, R. 1981/1993. Semantics: A New Outline. 2nd ed. Cambridge: Cambridge University Press.

Reisigl, M. 2008. Rhetoric of Political Speeches. In Ruth Wodak \& Veronika Koller (eds.). Handbook of Communication in the Public Sphere.Berlin, New York: Mouton de Gruyter.

Reiss, K. 2000. Translation Criticism - The Potentials and Limitations: Categories and Criteria for Translation Assessment. Translated by Erroll F. Rhodes. Manchester: St. Jerome Publishing.

Schaffner, C. 1996 Editorial: Political Speeches and Discourse Analysis. Current Issues in Language and Society 3, 3, 201204.

Shiyab, M. 2006. A Textbook of Translation. Belgium: Garant Publishers.

Shunnaq, T. 1993. Lexical Incongruence in Arabic-English Translation Due to Emotiveness in Arabic, in Turjuman 2.2, 3763.

. 1998. Problems in Translating Arabic Texts into English. In 
148 Lexical Incongruity in Translations of American Political Speeches into Arabic

Shunnaq, Abdullah; Dollerup, Cay and Saraireh, Mohammed (eds.). 1998. Issues in Translation. Irbid: Irbid National University, 33-52.

Shunnaq, A \& F. Mohammed. 1999. Translation with Reference to English \& Arabic: A Practical Guide. Jordan: Dar Al-Hilal For Translation.

Sirriyya, A. 1998. Translating Islamic Non-Quranic Religious Texts into English. Unpublished M. A. Thesis. Baghdad: AlMustansiriyya University.

Snell-Hornby, M. 1988. Translation Studies: An Integrated Approach. Amsterdam: John Benjamins Publishing.

Toury, G. 1987. Integrating the cultural dimension into translation studies: An introduction. In Translation Across Cultures, New Delhi: Bahri Publications Private Ltd.

Waard, D. \& N. Eugene. 1986. From One Language to Another: Functional Equivalence in Bible Translating. Nashville: Thomas Nelson Publishers.

Zgusta, L. 1971. Manual of Lexicography. Czechoslovak: Academia. Zughbi, M. 2010. Arab-Americans Turning Away from Bush. Available at URL <http://www.msnbc.msn.com/id/6056602/>

Yasmin H. Hannouna

Dept. of Translation Studies

Faculty of Humanities and Social Sciences

UAE University

P.O.Box 69571 Al-Ain-UAE

Phone number: 00971-50-1383564; Email: yasminhannouna@uaeu.ac.ae

Received Mar. 2010; Reviewed Apr. 2010; Revised version received May 2010. 